\title{
ATTITUDES OF RURAL FAMILIES' HEADS TOWARDS ENROLLING THEIR CHILDREN IN THE TECHNICAL EDUCATION IN SOME VILLAGES OF KAFR EL SHEIKH DISTRICT
}

(Received:20.7.2019)

\author{
By \\ G. M. A. El-shaer and M. Y. A. Radwan \\ Department of Rural Sociology, Faculty of Agriculture, Al-Azhar University, Cairo, Egypt
}

\begin{abstract}
The research aimed to determine the knowledge of families' heads about the importance of the technical education, the reasons that led the heads of families to enroll their children in the technical education, attitudes of rural families' heads towards enrolling their children in the technical education; and determining the problems facing when enrolling their children to the technical education and their proposals to overcome them. The research was conducted on 120 respondents from the heads of rural families who have children in preparatory education, as the largest administrative district was selected; from which the three largest villages in terms of the number of students in preparatory education were selected. Data were collected through a questionnaire during February and March 2019. After that, the data have been discharged and analyzed statistically, tables, percentages, simple correlation coefficient, Chi square, and average degree were used .The results showed the following:

- The reason that technical education provides the student with the skills that enable him to perform his work ranked first.

- The reason for escaping from the high school education conflict was ranked first in the reasons that encourage the families to enroll their children in the technical education.

- The results indicated that there was an average general tendency for the respondents to enroll their children in the technical education.

- There was a positive significant relationship between the number of family members of families' heads and their knowledge of the importance of the technical education.

- There was a negative significant relationship between the monthly income of the families' heads and their knowledge of the importance of the technical education.

- There was a significant relationship between the profession, the educational status of the respondents and their knowledge of the importance of the technical education.

- There was a positive significant relationship between the age of the respondents and their opinion about the importance of the reasons that encourage them to enroll their children in the technical education.

- There was a negative significant relationship between the monthly income of the respondents and the importance of the reasons that encourage them to enroll their children in the technical education.

- There was a positive significant relationship between the area of agricultural holdings, the monthly income, the cultural openness, and the age of the respondents and their tendency to enroll their children in the technical education.

- The most important problems that hinder the respondents when enrolling their children in the technical education were: weak financial and human resources in the technical schools to train students practically, low societal outlook for the technical education compared to the university education, and lack of job opportunities for graduates.

- The most important proposals of the respondents to overcome the problems that hinder them to enroll their children in the technical education were: Re-consideration by the State in the interest of the development of technical education and increase its budget, and provide employment opportunities for graduates in the form of profitable projects and facilitate their procedures without mediation or nepotism, commensurate with the labor market. The research siggested several recommendations derived from its results.
\end{abstract}

Key words: Kafr el sheikh, technical education, families' heads. 
إتجاها ت أرباب الأسر الريفيين نحو إلحاق أبنائهم الطلاب بالتعليم الفنى ببعض قرى مركز كفر الثيخ

جمال محمد أحمد الشاعر - مصطفى يوسف ابو زيد رضوان

$$
\text { قسم الإرشاد الزر اعى والمجتمع الريفى - كلية الزراعة - جامعة الأزهر - القاهرة }
$$

\begin{abstract}
ملخص

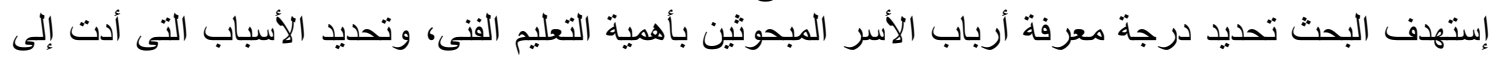

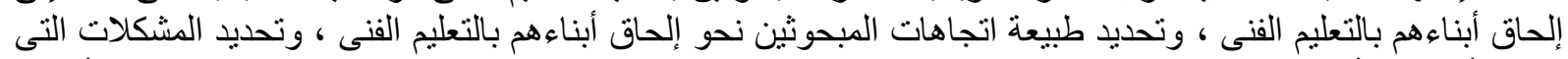

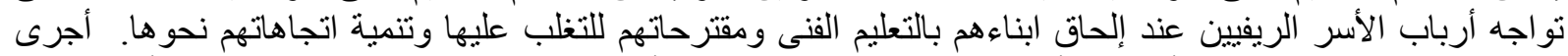

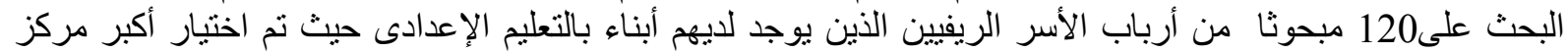

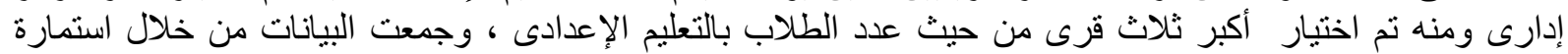

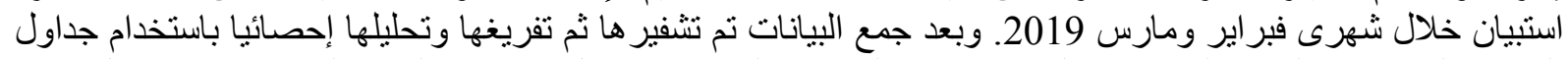

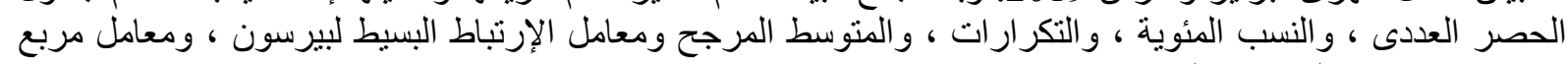

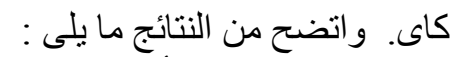

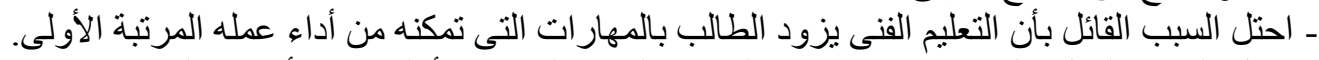

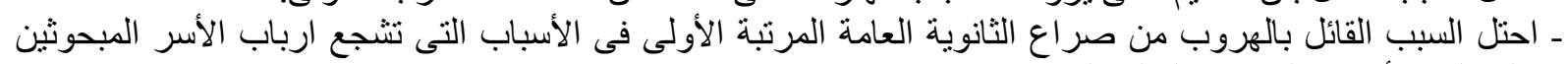

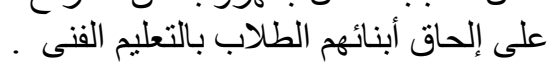

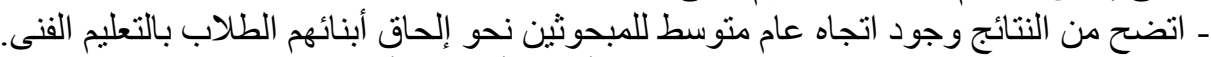

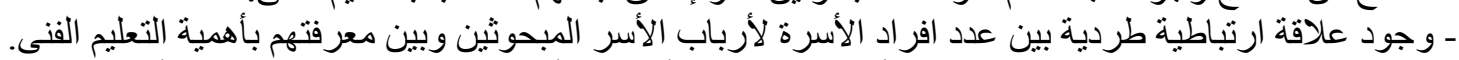

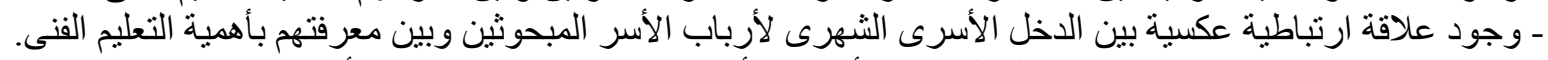

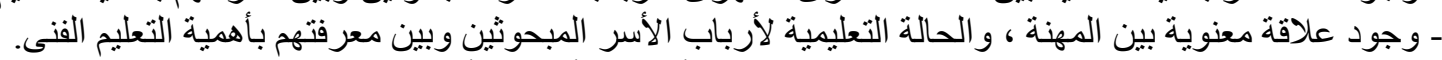

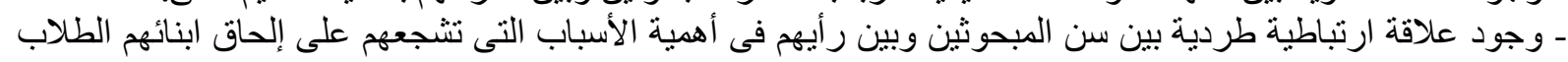

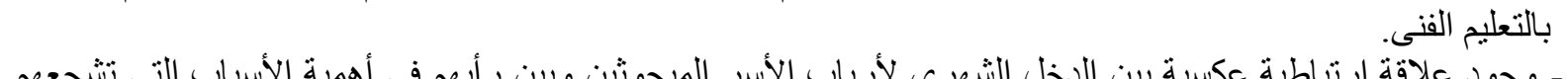
- وجود علاقة ارتباطية عكسية بين الدخل الثهرى لأرباب الأسر المبحوثنين وبين رأيهم فى أهمية الأسباب التى تشجعهم

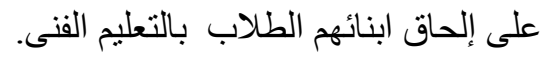

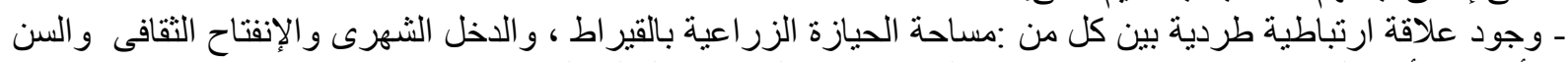

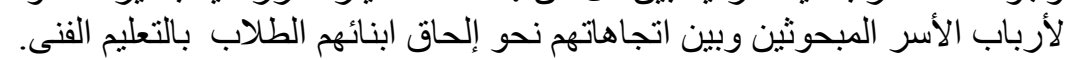

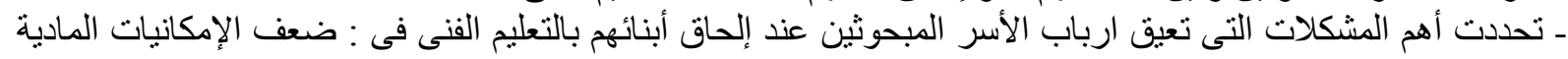

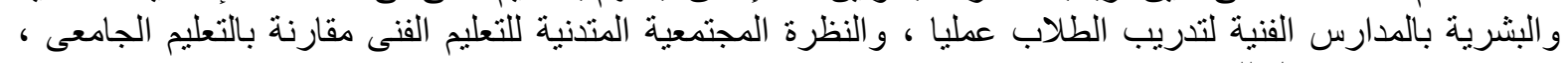
و عدم توفر فرص بالمدارس عمل للخريجين.

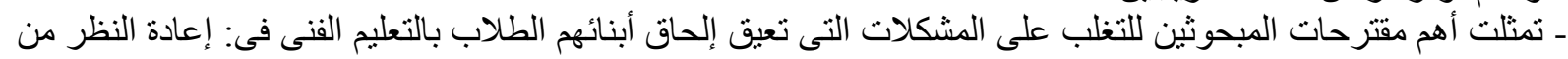

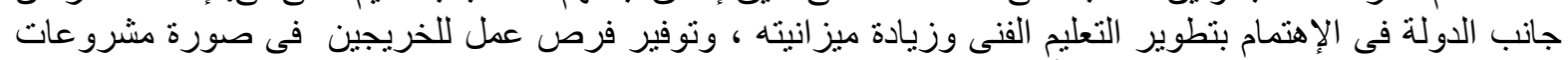

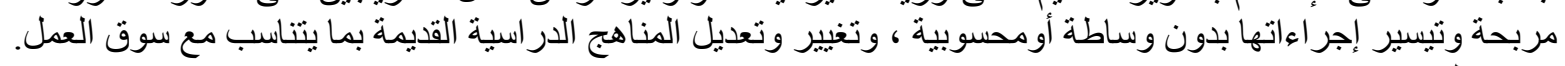
- و انتهى البحث بعدة توصير إجرات مستمدة من نتائجه.

المتعددة بعداً مهماً من أبعاد التتميـة الثـاملة لإقامـة

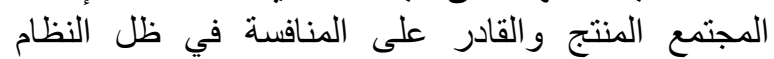

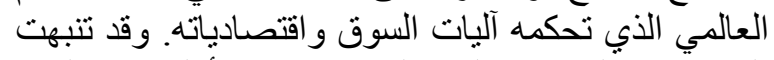

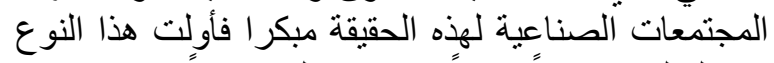

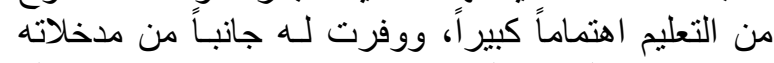

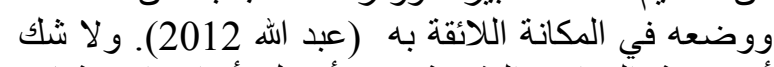

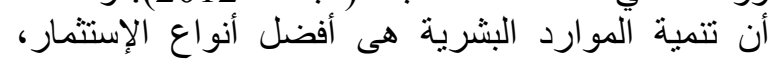

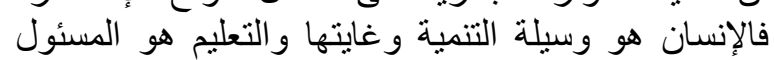

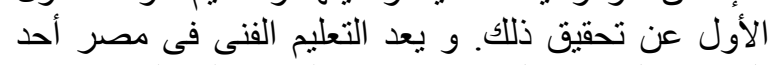

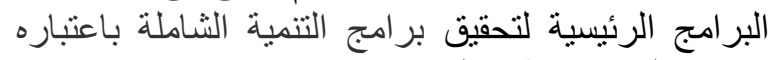

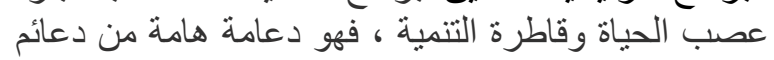

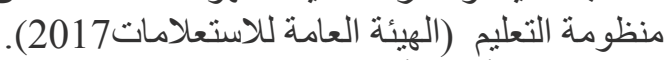
ويبدو أن مسألة الاهتمـام بـالتعليم الفنى قضينة قديمة

\section{1. المقدمة و المشكلة البحثية}

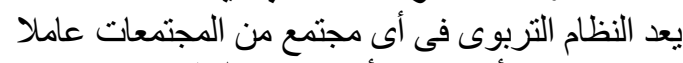
فعالا فى تحقيق أهداف وأغراض الفئ النظم الإجنماعية

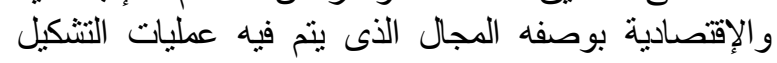

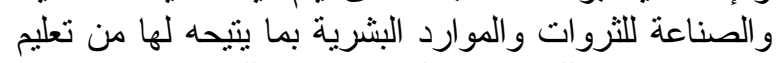

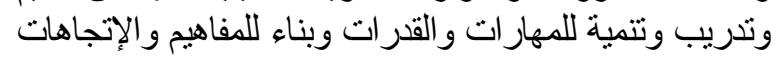
(مرسى، 1993).

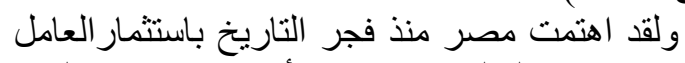

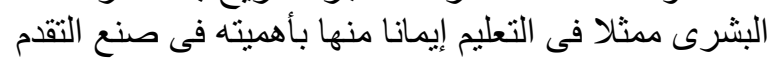

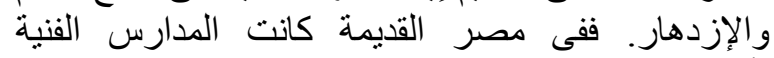

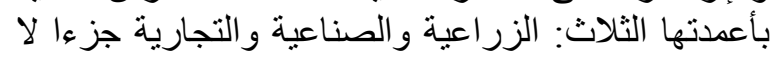

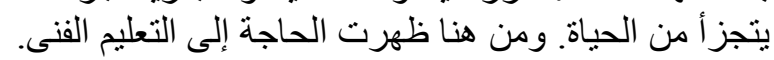
ويمثل كل من التعليم الفني والتندريب المهني بصوره 


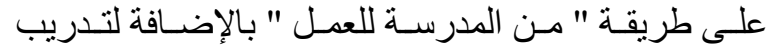

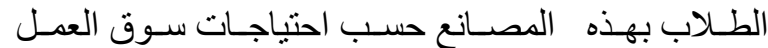

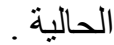

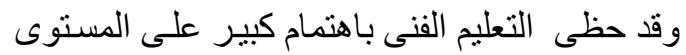

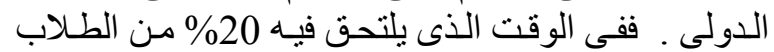

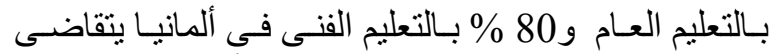

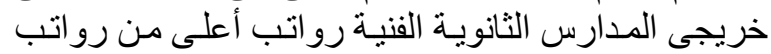

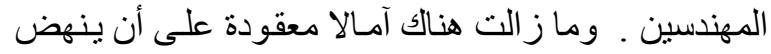

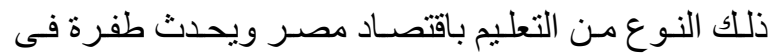

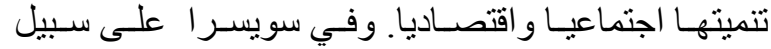

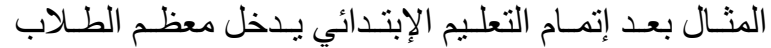

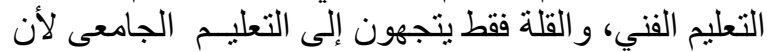

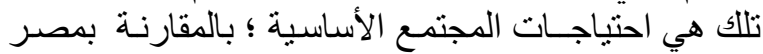

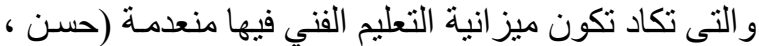

وتتضح أهمية التعليم الفنى فى مصر طبقا لكل من

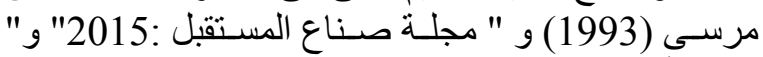

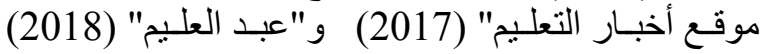

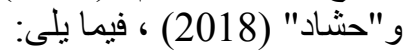
1- التعليم الفنى يزود الطالب بالمهار ات و المعلومات الفئ الفنية التى تمكنه من أداء عمله.

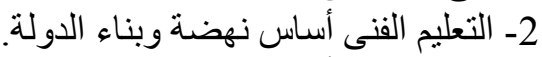

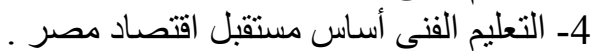
5- التعليم الفنى يعطى فرصة للطالب للحصول على وظيفة

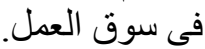

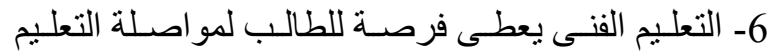

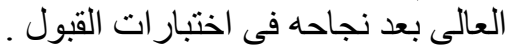

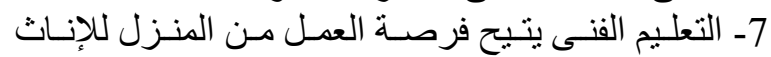

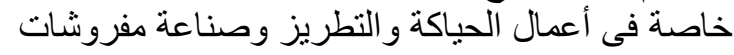

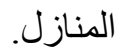
8- التعليم الفنى يمنح الطلاب ثقة كبيرة ودرجة عالية فى الإعتماد على النفس.

9- التعليم الفنى يمنح للخريجين شهادات معترف بها دوليا.

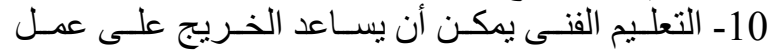

مشروع صغير غبر مكلف بما يحقق له له دخل سنوى النه

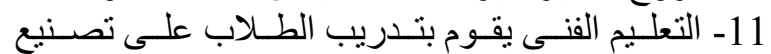
منتجات معينة وبيعها للمستفيدين منها.

12 - التعليم الفنى ضرورة لرئة لرفع مستوى معيشة الريفيلين.

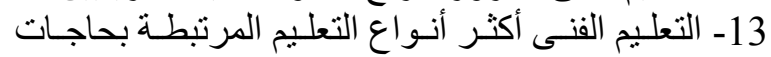

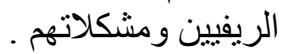

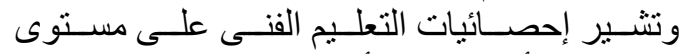

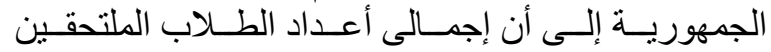

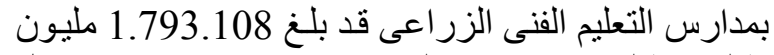

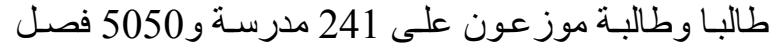

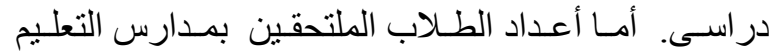

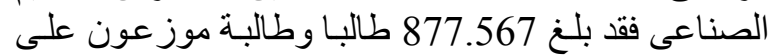

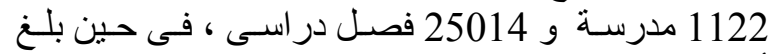

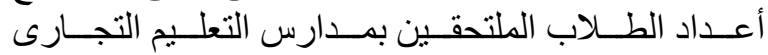
705.172 طالبا. أما على مستوى محافظة كفر الثيخ فقد الند

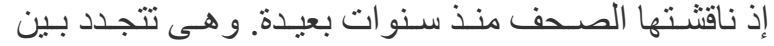

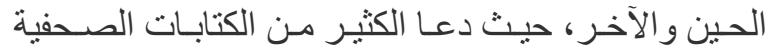

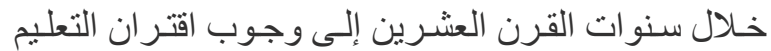

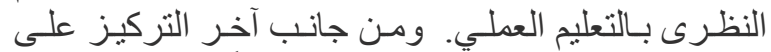

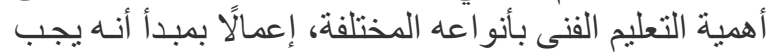

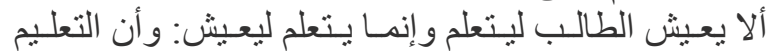

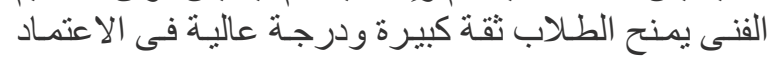

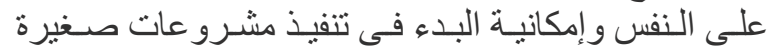

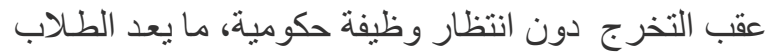
لمو اجهة معترك الحياة وتحقيق الذات (صديق التئ ، 2018).

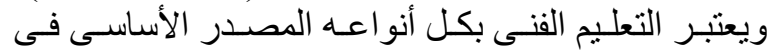

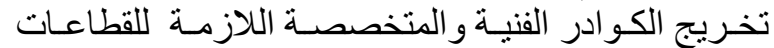

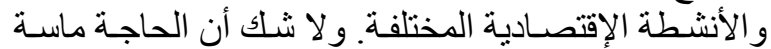

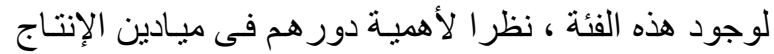

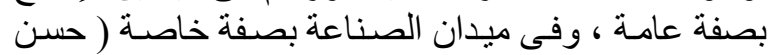
وخليل ، 2003)

ويقصد بالتعليم الفني في دائرة المعارف البريطانية

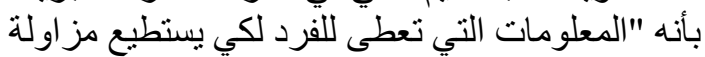

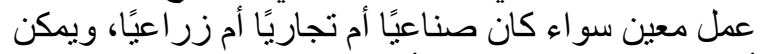

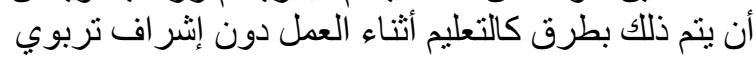

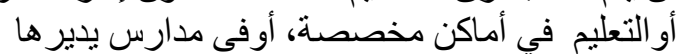

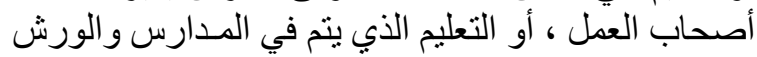

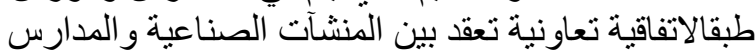

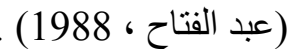
كما يعرف التعليم الفنى بأنه " ذللك النوع من التعليم

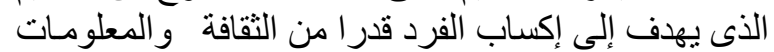

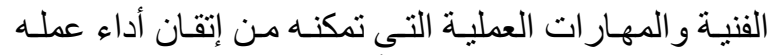

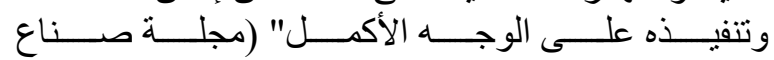
المستقبل،2015).

لقد اصبح الاهتمـام بالتعليم الفنى (العملى) ضروريا

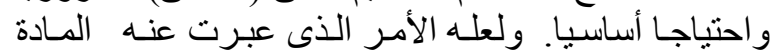

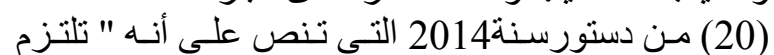

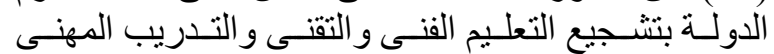

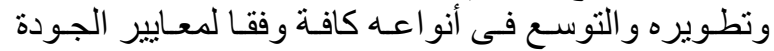

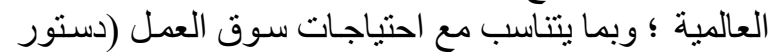

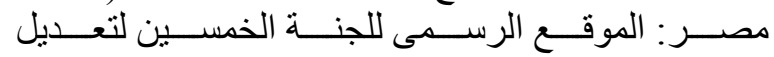

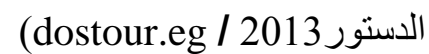
وفى إطار إصلاح التعليم الفنى و التدريب المهنى فقد

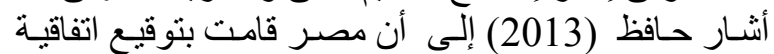

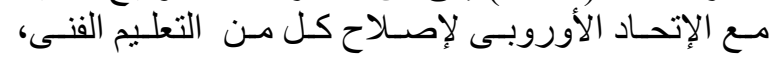

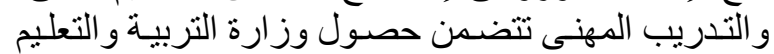
على 50 مليون يورو لتطوير القطاعين خلال 3 سنوات

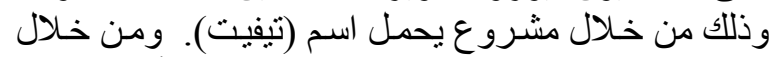

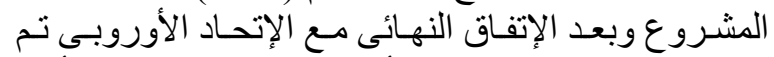
إنشاء ما بسمى (التدريب من أجل التشغيل التيل والتعليم من أجل التبل

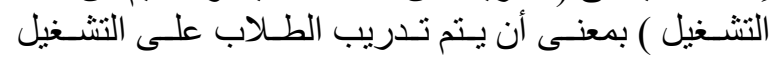

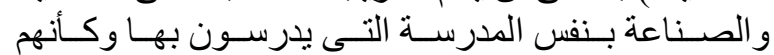
أصحاب مشروعات صناعة بـاعية . كما يتضمن الإتفاق إنشـاء

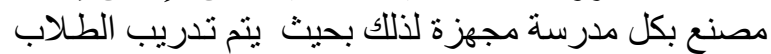


الحرير (صالح،2017)و و(موقع tawgeh.yoo7.com ). و على الرغم مـن الأسباب التـي تشـجع أربـاب الأسـر

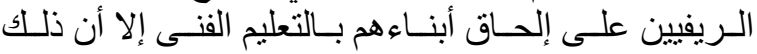

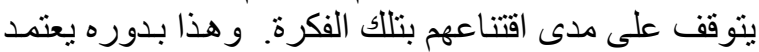
على ما إذا كانت اتجاهاتهم إيجابية نحو التعليم الفنى أم لا. لا.

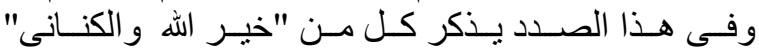

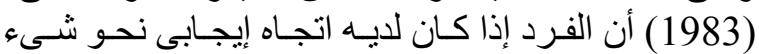

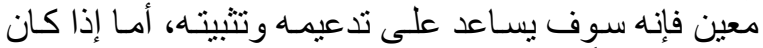

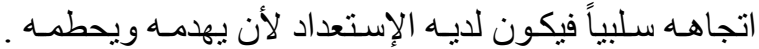
فالإتجاهات تقوم بدور كبير في توجيه سلوك الإن الفرد وتحديد

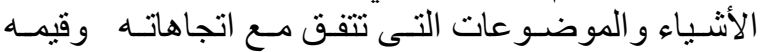
ومعتقداته، ورفض الأشياء التى لا تتفق مع اتجاهاته وقيمـهـ

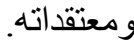

ويعرف عوض (1991) عن بوجاردس الإتجاه بأنه " بونها

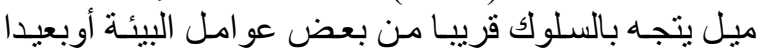

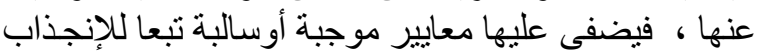
نحوها أو النفور منها ". كما يعرف عبد الرحيم (1981) الإتجاه بأنه " استعداد التفاد

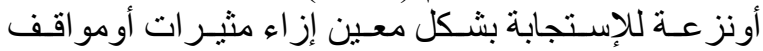

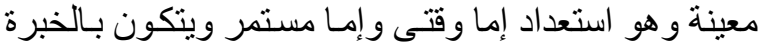

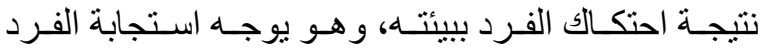

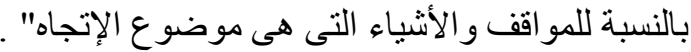

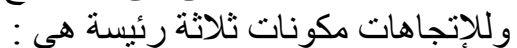

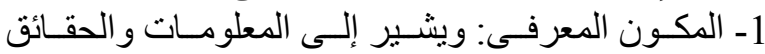

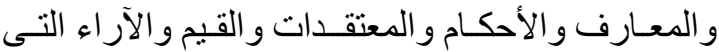

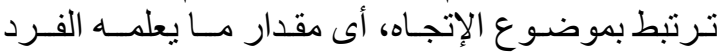

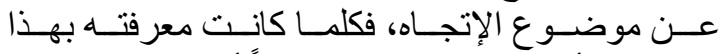

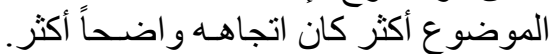

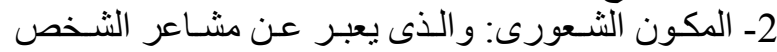

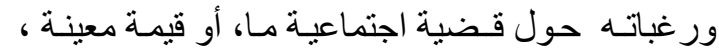

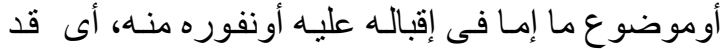

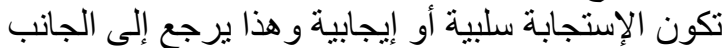
العاطفى لكل إنسان .

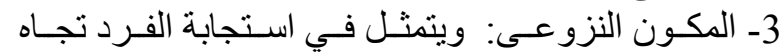
موضو ع الإتجاه بطريقة مـا، قد تكون سلبية أو إيجابيـة (نشوانى 1983). وبناء على ما سبق فان معرفة اتجاهات أربات ألفاب الأسر

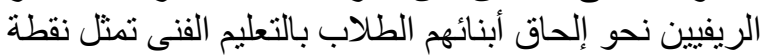

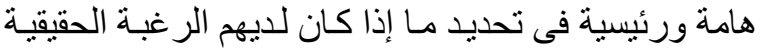

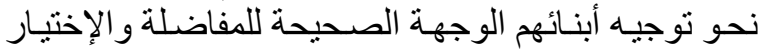

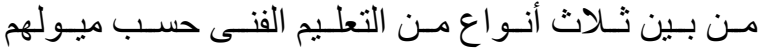

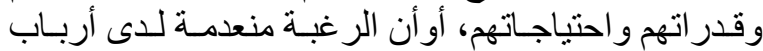

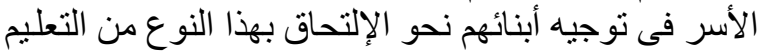

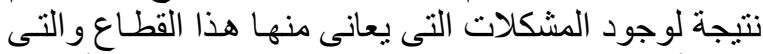

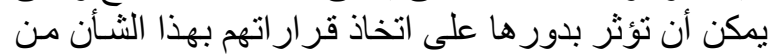

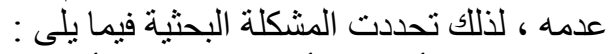

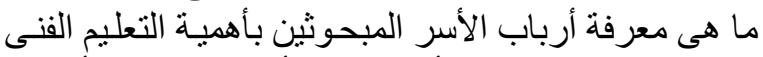

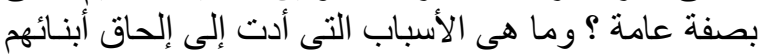
به؟ ومـا هى طبيعة اتجاهاتهم نحو إلحاق أبنائهم بالتعليم التهاتي

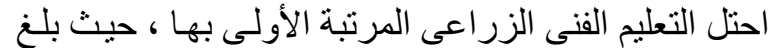

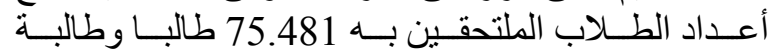

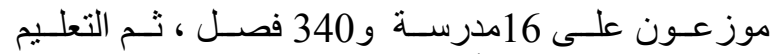

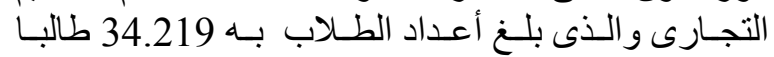

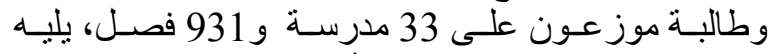

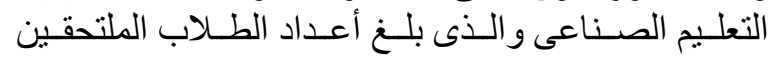

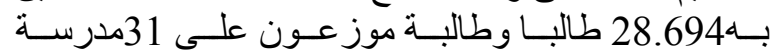

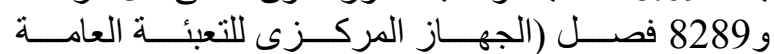
و الإحصاء، وناء2817).

وطبقا لاحصائيات "الجهاز المركزى للتعبئة العامـة و الإحصاء " 2016" يبلغ أعداد الطلاب بالتعليم الإعدادى للادي العادي على مستوى محافظة كفر الثيخ 204.513 طالبا وطالبة الإلة

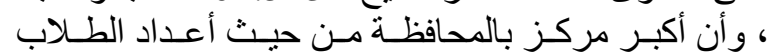

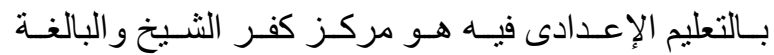

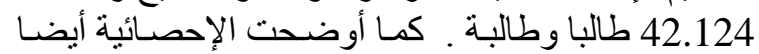
أن أكبر 3 قرى من حيث أعداد طلاب التعليم الإعدادى بهاليها

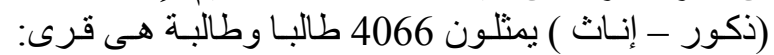

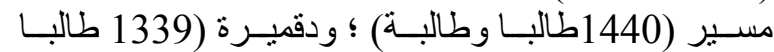
وطالبة) ؛ومحلة القصب (1287 طالباوطالبة). و لا شـك أن هنـاك أسبابا عديدة تدفع أربـاب الأسـر

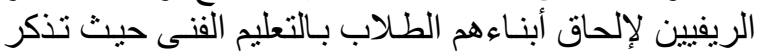

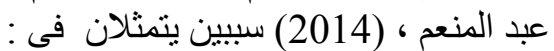

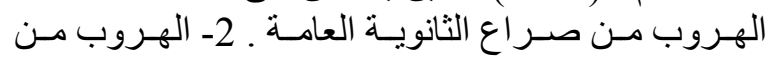
الدروس الخصوصية.

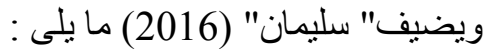
3- المنافسة مع الزملاء في ملى مرحلة الثانوية العامة 4- التأكيد على أن التعليم الفنى لا يقل أهل أهيـة عن التعليم العطام .

5- التعليم الفنى غير مكلف كمـام يضـيف عبد المقصـود،

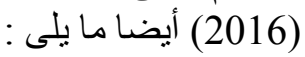
6- ضنعف المجموع.

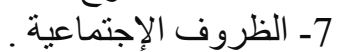

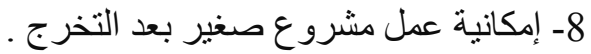

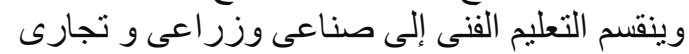
سواء نظام الثثلاث سنوات أو نظام الخمس سنو الت اتى لخريجى

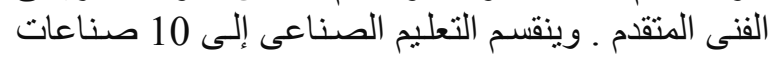

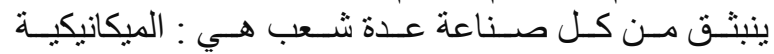

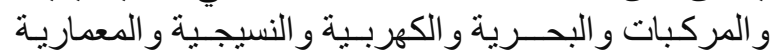

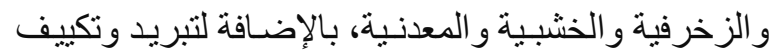

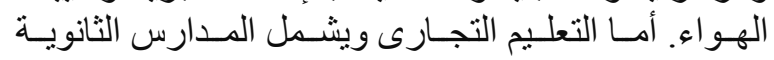

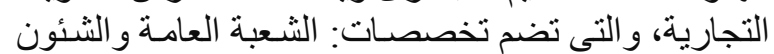

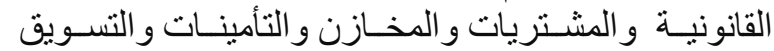

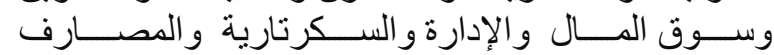

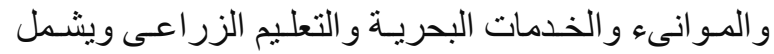

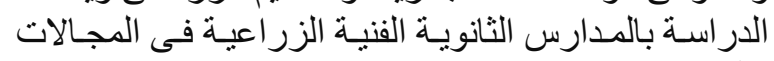

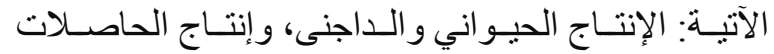

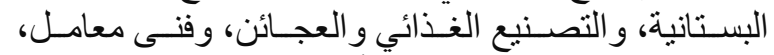

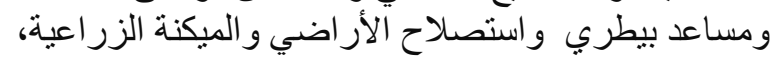
وتكنولوجيا إنتاج وتصنيع الأسماك، وتربية الأية النحل وديدان الزرانة 


$$
\text { إلحاق أبنائهم الطلاب بالتعليم الفنى . }
$$

الفروض الإحصائية

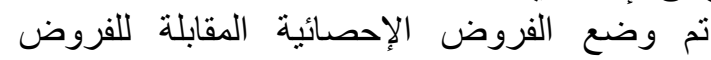

البحثية لإثبات عدم وجود علاقة بين المتغيرات المبنة المستقلة

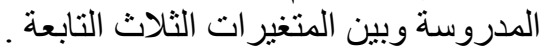

\section{2. - 2. - 2 الطريقة البحثية}

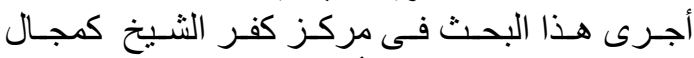

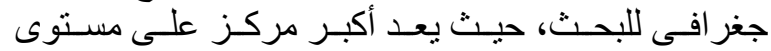
المحافظة من حيث عدد طلاب الثهادة الإعداديـة المقبلين

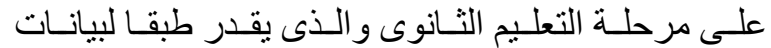

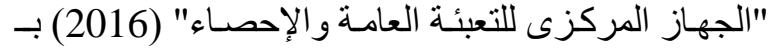

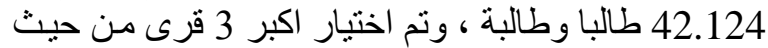

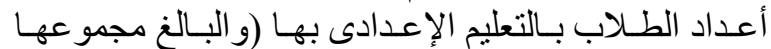

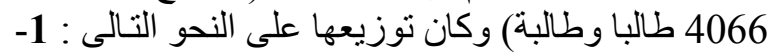

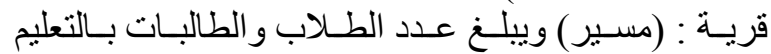
الإعدادى فيها (1440) طالبا وطالبة . 2- قرية : (دقميرة)

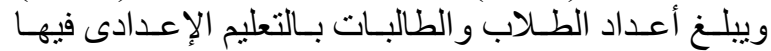

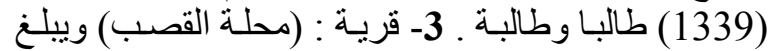
أعداد الطلاب و الطالبـات بـالتعليم الإعدادى فئها فيا (1287)

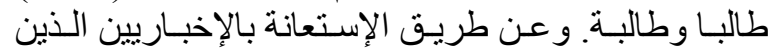

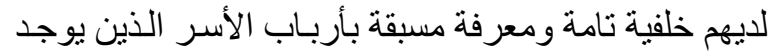

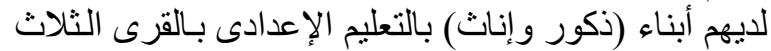

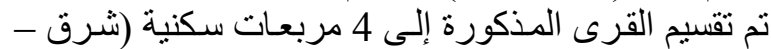

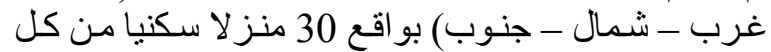

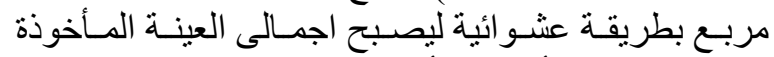

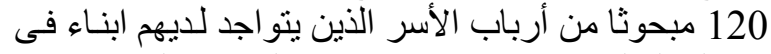

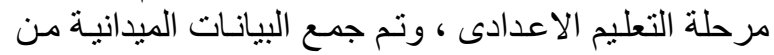

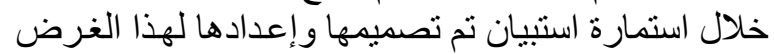

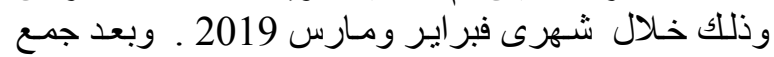

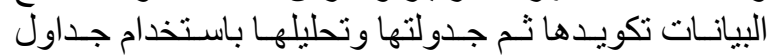

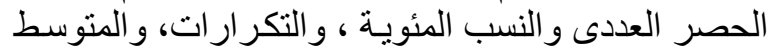

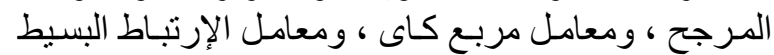
لبيرسون وقد اشتملت استمارة الاستبيان على سبعل الارتيام أقسام

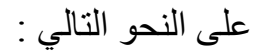

القسم الأول: و اشتنمل على المتغيرات المستقلة لأرباب

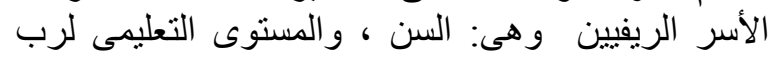

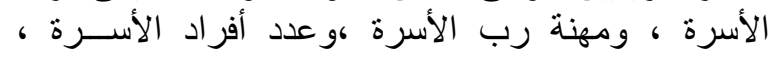

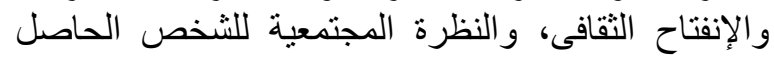

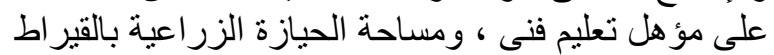

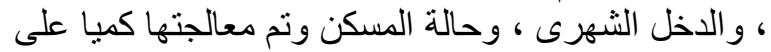

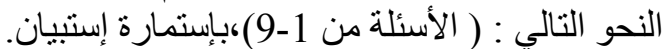

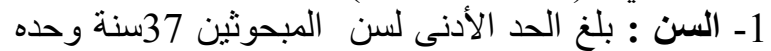

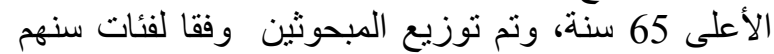

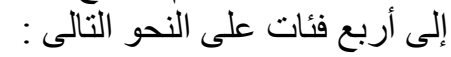

$$
\begin{aligned}
& \text { ـ - 3ن - 43- } 43 \text { سنة } \\
& \text { ـ - من -44- } 51 \text { سنة } 51 \text { سنة } \\
& \text { - من52 - } 58 \text { سنة }
\end{aligned}
$$

الفنى؟ ومـا هـى المشكلات التى تعبقهم عن إلحساق أبنائهم

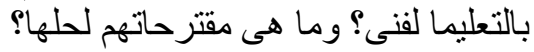

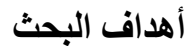

بناء على مشكلة البحث السابق عرضها فقد تحددت أهدافه

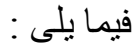

1-تحديد درجة معرفة أرباب الأسر المبحوثين بأهمية

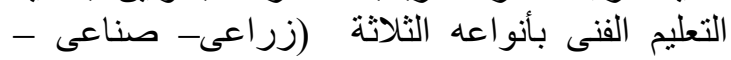
تجارى) بصفة عامة .

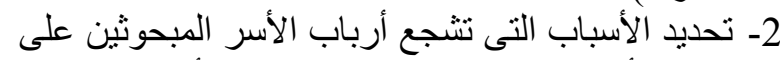

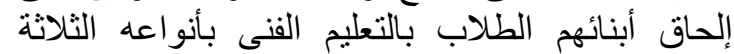

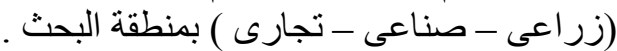

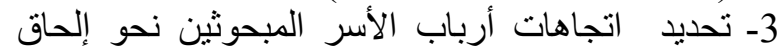

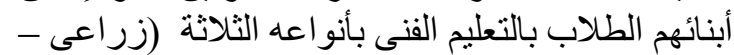
صناعى - تجارى ) بمنطقة البحث.

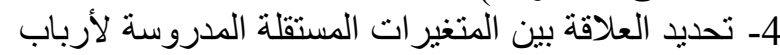

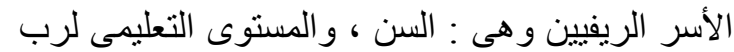

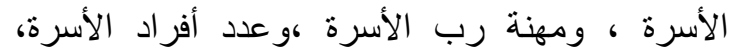

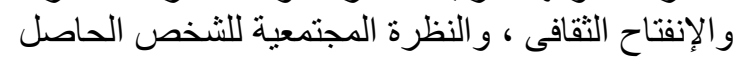

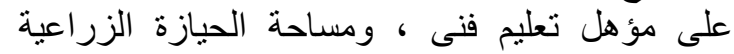

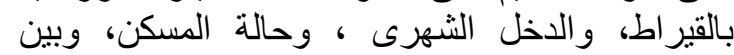
معرفتهم بأهمبة بالتعليم الفنى بأنو اعه الثناثنة (زر اعى الثى

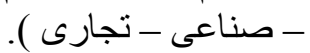

5- تحديد العلاقة بين المتغير ات المين المستقلة المدروسة لأرباب

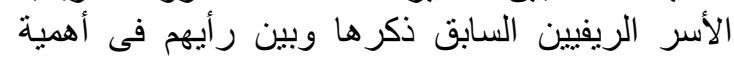

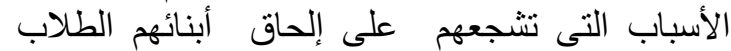

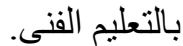
6- تحديد العلاقة بين المتغير ات المستقلة المدروسة لأرباب الأسر الريفيين وبين اتجاهاتهم نحو إلحاق العناق أبنائهم

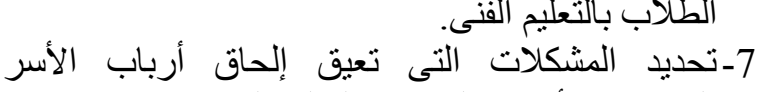

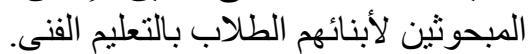

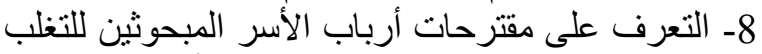

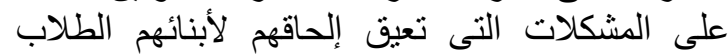

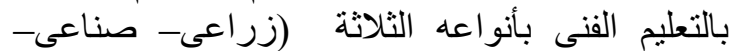

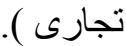
الفروض البحثية 1توجد علاقة بين المتغير ات المستقلة المدروسة لأرباب

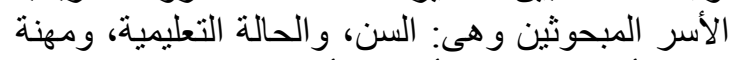
رب الأسرة ، و عدد أفراد الأسرة، والإنفتاح الثقافى،

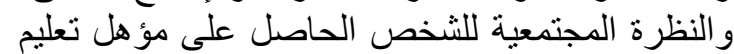

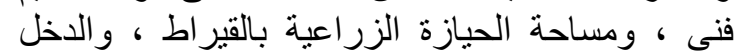
الثهرى، وحالة المسكن، وبين معرفتهم بأهمية التعليم الزيخ الفنى . 2-توجد علاقة بين المتغير ات المستقلة المدروسة لأرباب

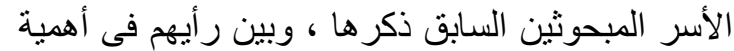

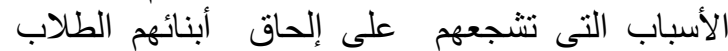

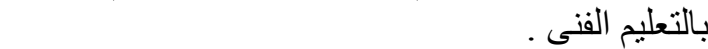
3-نوجد علاقة بين المتغير ات المستقلة المدروسة لأرباب الأسر المبحوثين السابق ذكرها، وبين الجاهاتهم نحو لأبراب 


$$
\begin{aligned}
& \text { نظرة متدنية (9-10) درجات } \\
& \text { نظرة متوسطة (11-13) درجة دئة (11) درجة } \\
& \text { نظرة مرتفعة (14-15) درجة }
\end{aligned}
$$

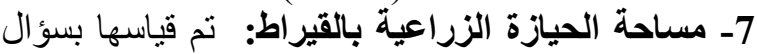

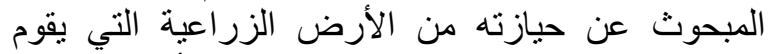

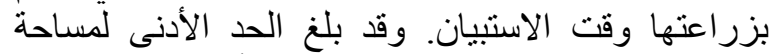
الحيازة الزراعية 5 قراريط وحدها الأعلى 50 قير اطا. وتم تقسيم المبحوثين من حيث حيازتهم الزراعية للفئات

حيازة منخفضة (5-19) قير اطا مناز

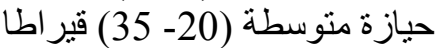

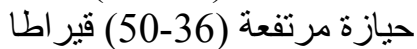

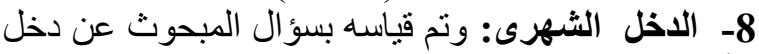

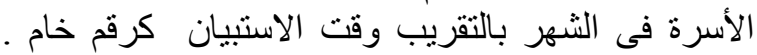
وقد بلغ الحد الأدنى للاخل الثهرى للأسرة 700 جنيه وحده الأعلى 7000جنيه، وبناء على ذللك تم تقسيم المبحوثين للفئات التالية :

- دخل منخفض (700- 2799) (2800) جنيهان

-دخل متوسط (2800- 4خل منفط (2899) جنيها

-دخل مرتفع (4900-

9- حالة المسكن : تم قياسها بسؤ ال المبحوث عن البنود

التالية :

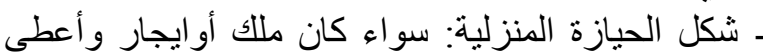
للأول درجتان و للثانى درجة واحنة المدة.

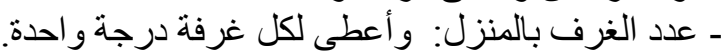

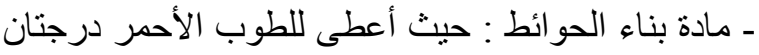
، وللطوب اللبن درجة و واحدة. ـ دهان الحو ائط: أعطى للاهدان بالزيت 4 درجات درجات ، و و الجير

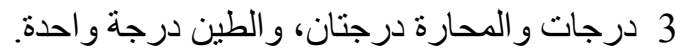
- نوع السقف: أعطى للخرسانة درجتان ، وللخشب درجة درجة و واحدة

- نوع الأرضية: أعطى للسير اميك 4 درجات و البلاط 3 درة

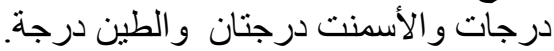

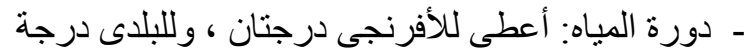
و واحدة. ـ المطبخ : أعطى لمن لديه مطبخ درجنان و ومن ليس لديه درجة واحدة. وجمعت الدرجة الكلية للبنود الثمانية لتعبر عن حالة مسكن المبحوث وقد بلغ الحد الأدنى للمدى الفعلى لحالة المسكن 15 درجة وحده الأعلى 30 درجة. وبناء على ذللك تم تقسيم مسكن المبحوثين وفئ وفقا لحالته لايهم

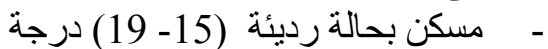

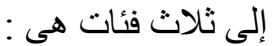

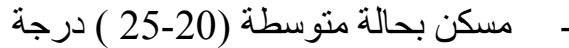

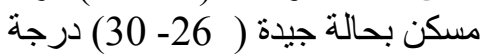

القسم الثانى : واختص بتحديد درجة معرفة أربدة أرباب الأسر

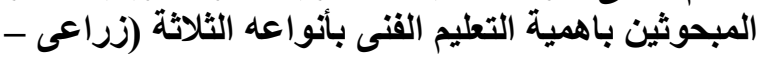

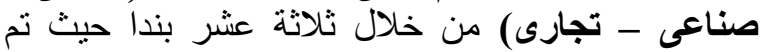
استبيان المبحوثين عن معرفتهم بتلك البنود الثناثة عشر تشر

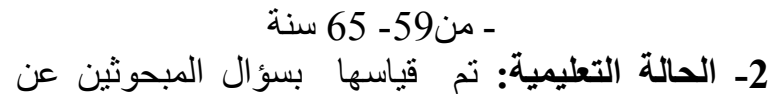

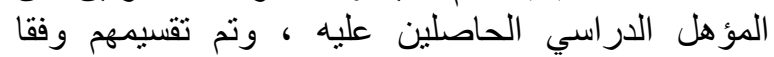

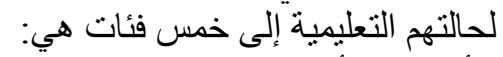

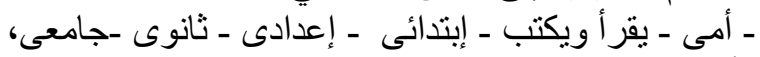

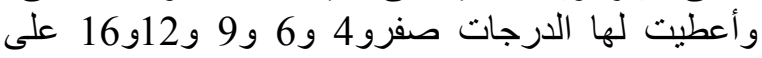
الترتيب للترميز

3- مهنة رب الأسرة : تم قياسها بسؤال المبحوثين عن الأن مهنتهم الأساسية التى يعملون بها وتم تقسيمهم وفقا لمهنتهم

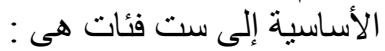

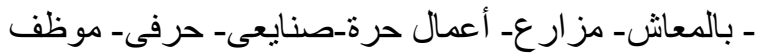

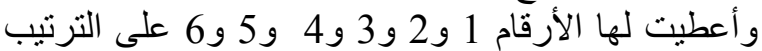
للتر ميز.

4- عدد أفراد الأسرة: تم قياسه بسؤال المبحوث عن عدد أند

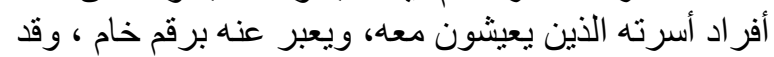

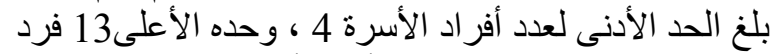

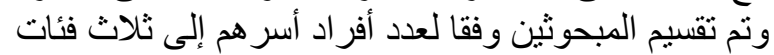

ـ أسرة قليلة العدد (4-6) أفر اد

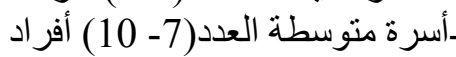

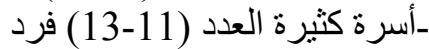

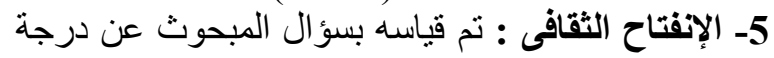

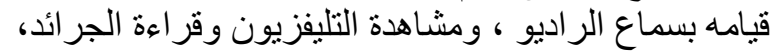

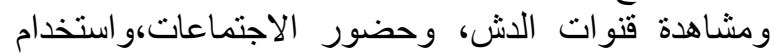
النت،وذلك على مقياس مكون من اربع فئات هـى هون: دائما

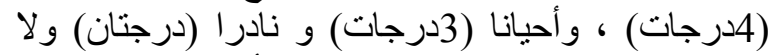
يكون (درجة واحدة) وقد بلغ الحد الأدنى للمدى الفى الفعلى (دردانى للانفتاح الثقافى للمبحوثين 6 درجات ورجات وحده الأعلى 24 درجة. وتم تقسيم المبحوثين وفقا لانفتاحهم الثقافى إلى لـى لأى ثلات فئات هي:

ـ انفتاح بدرجة منخفضة (1-11 (11) ) درجة

ـ انفتاح بدرجة متوسطة (12-18) درجة منة منة

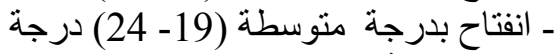

6- النظرة المجتمعية للشخص الحاصل على مؤهل تعليم

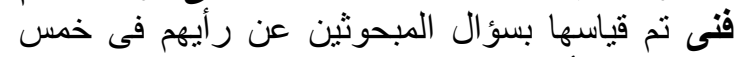

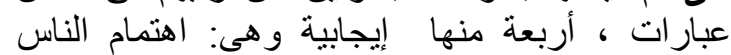

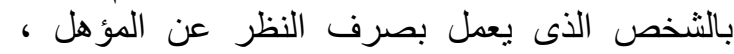
وتغير النظرة للتعليم الفنى فى ظل الظروف الته التى تعيشها

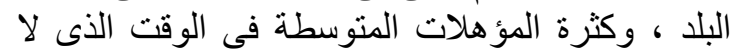

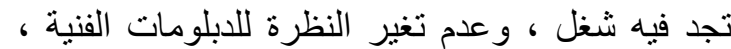
و عبارة واحدة سلبية وهى: احتياج البلد للمؤهية هلات العليا عن المتوسطة ، وذللك على مقياس مكون من ثنات احثن فئات

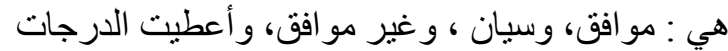

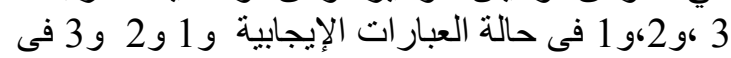

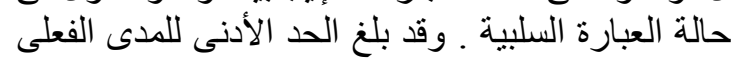

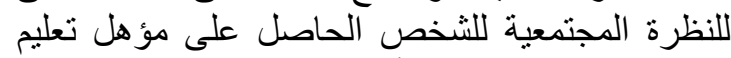

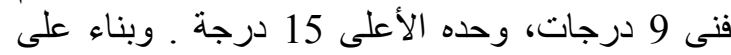

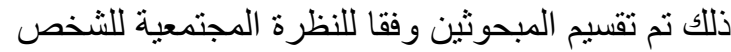

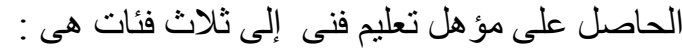


وذللك على مقياس مكون من أربع فئات هى: هام

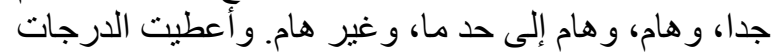

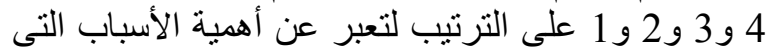

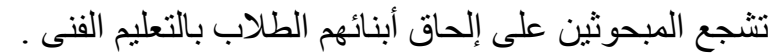

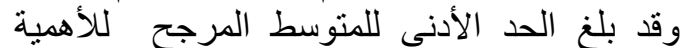

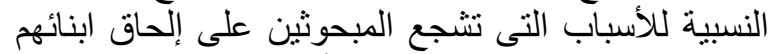

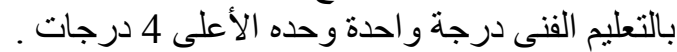

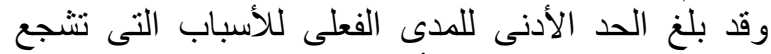

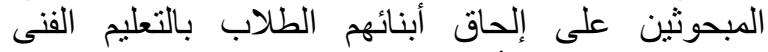

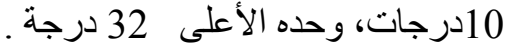
وبناءًا على ذلك تم تقسيم المبحوثين إلى أربع فئات هي :

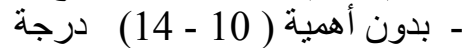

ـ أهمية بدرجة متوسطة (15 اهية - 15 - 19) درجة درجة

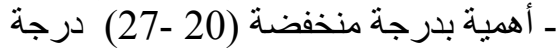

ـ أهمية بدرجة عالية (28-32) درجة.

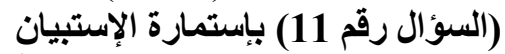

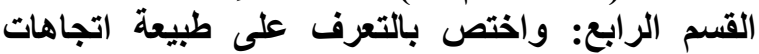

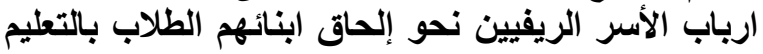

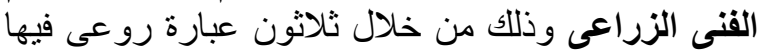

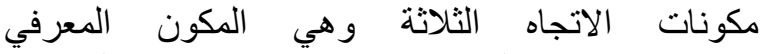

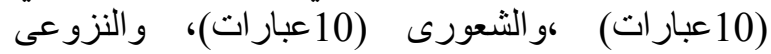

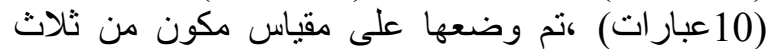

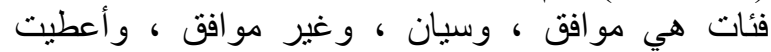
الدرجات 3 و2 و و في حالة العبار ات الايجابية، و واتو 2و 3

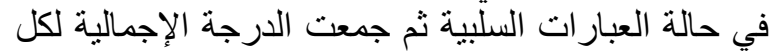
مكون لتعبر عن درجة المكون في الاتجاه وذللك على النحو الإل

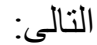

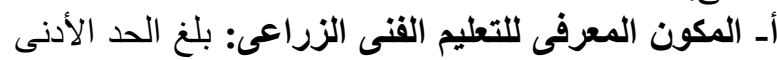

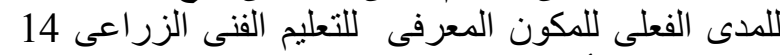

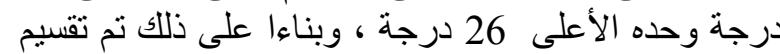
المبحوثين إلى ثلاث فئات هيى : مو افق (23-23) درجة سيان (18-22) درجة. غير مو افق (14-17) درجة هونة

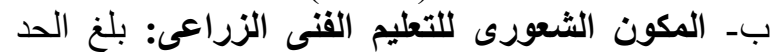

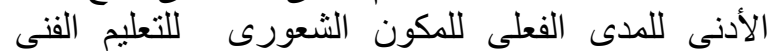

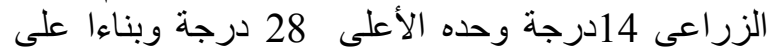

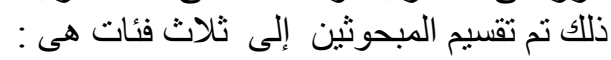
مو افق (24- 28 ) درجة فئن سيان (19 - 23) درجة غير موافق(14- 18) درجة

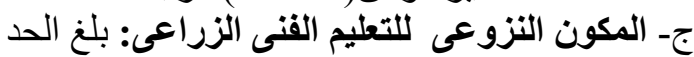

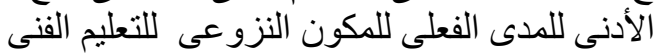

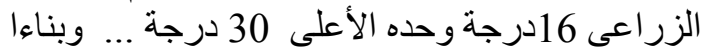

على ذللك تم تقسيم المبحوثين إلى ثناثل فئئات هى : مو افق (26- 30) درجة سيان (21-25) درجة غير موافق (16- 20 20 درجة درجة ولتحديد طبيعة الاتجاه نحو التعليم الفنى الزراعى بورجه
وهى:

1- التعليم الفنى بزود الطالب بالمهار ات و المعلومات الفنية التى تمكنه من أداء عمله.

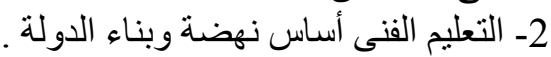

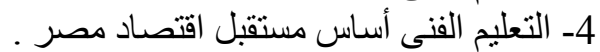

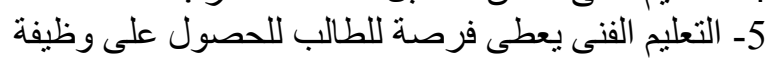

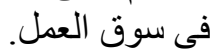

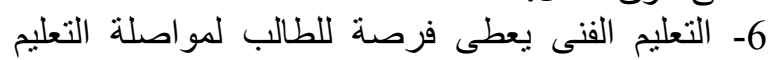
العالى بعد نجاحه في اختبار ات القئ القبول

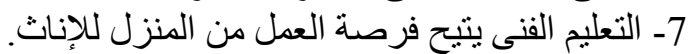

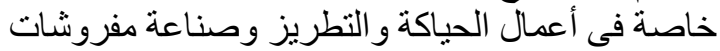

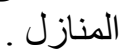

8- التعليم الفنى يمنح الطلاب ثقة كبيرة ودرجة عالية فى الإل الإعنماد على النفس.

9ـ التعليم الفنى يمنح للخريجين شهادات معترف بهاد دوليا

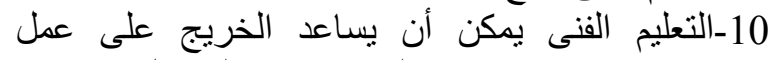

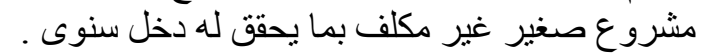

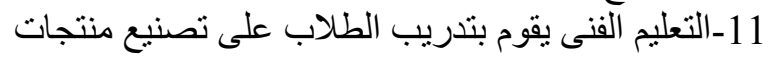

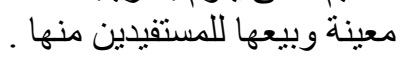

12- التعليم الفنى ضرورة لكئل لرفع مستوى معيشة الريفينين.

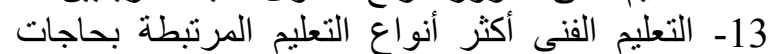

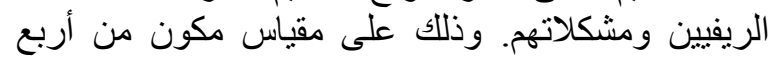

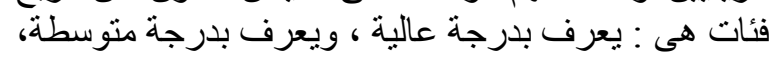

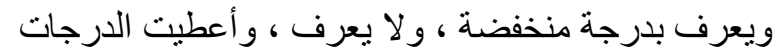
4 و 3 و2 و و 1 على الترتيب لتعبر عن معرفة المبحوثين بأهمية التعليم الفنى.

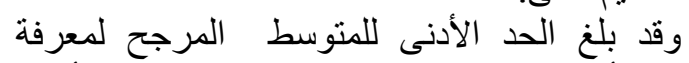

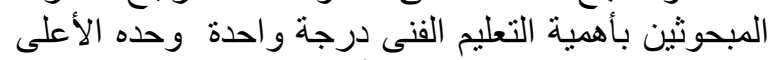

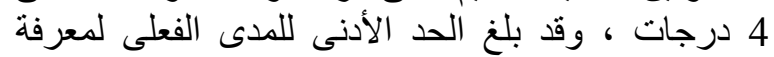

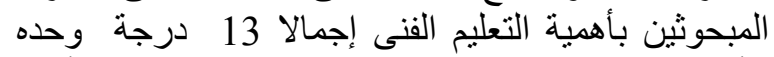

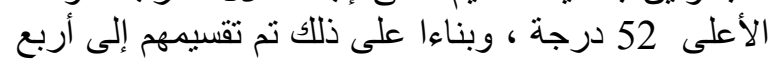

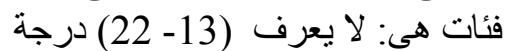

- معرفة بدرجة منخفضة (23 - 32 - 32) درجة درجة

ـ معرفة بدرجة منوسطة (33- 42 42 درجة درجة

ـ - معرفة بدرجة عالية (43 -52 (52) درجة درجة

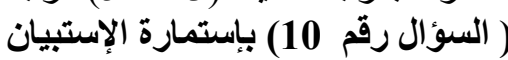

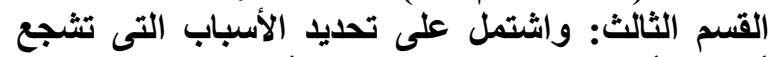

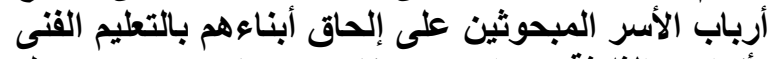

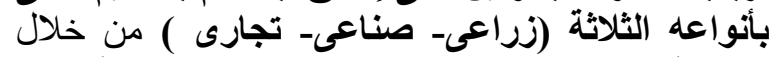

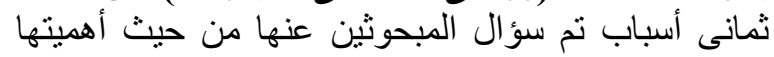

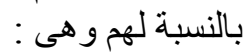
1- الهروب من صر اع الثنانوية العامة.

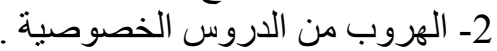

3- المنافسة مع الزملاء في مرحلة الثئ الثانوية العامة . 4-التأكيدعلى أن التعليم الفنى لا بقل الهيل أهمية عن التعليم العام 5- التعليم الفنى غير مكلف. التعائ.

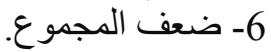

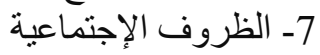
8- إمكانية عمل مشروف الإنماعة صغير بعد التخرج. 


$$
\begin{aligned}
& \text { اتجاه منخفض (15- } 19 \text { ) درجة } \\
& \text { اتجاه منوسط (20- } 25 \text { ) درجة } \\
& \text { اتجاه مرتفع (26- 30) درجة }
\end{aligned}
$$

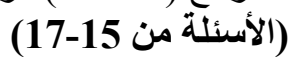

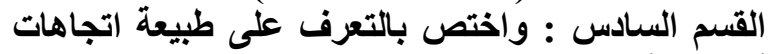

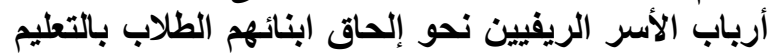

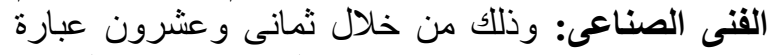

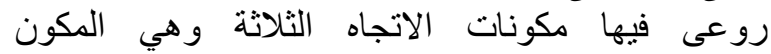

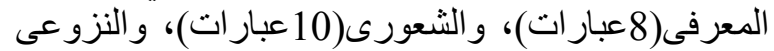

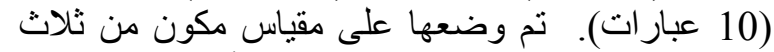

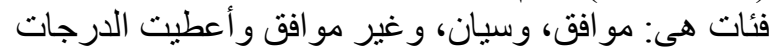

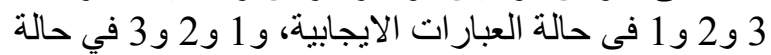

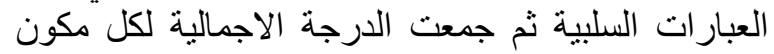

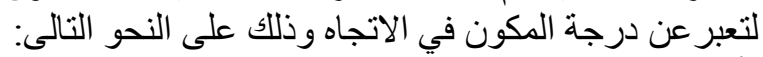

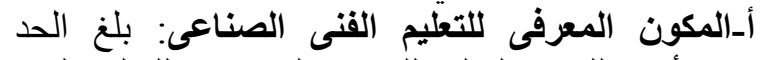

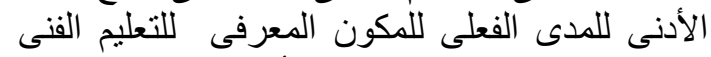

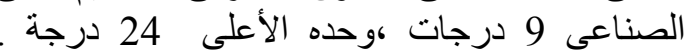
وبناءا على ذلك تم تقسيم المبحوثين إلى ثلاث فئات

$$
\text { غير مو افق ( } 14 \text { - 20- 19) درجة درجة } 14 \text { دوانة }
$$

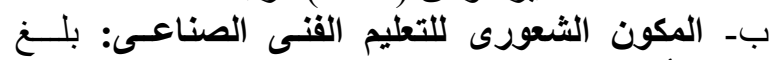

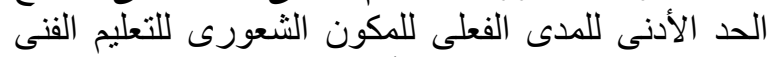

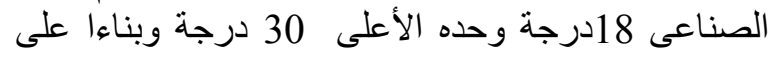

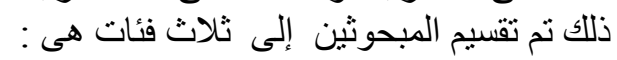

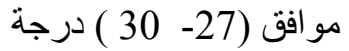
سيان ( 22 - 26) درجة (30) درجة غير مو افق( 18 - 21 21) درجة درجة

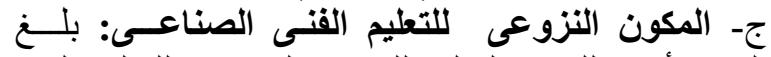

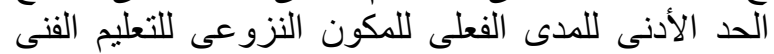

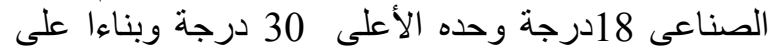

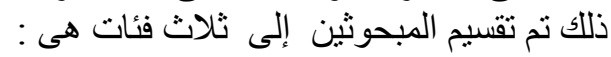
مو افق (27- 30) درجة سيان (22-26) درجة درجة غير مو افق (18-21-21) درجة

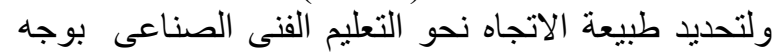

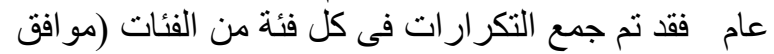

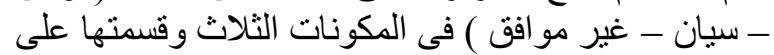

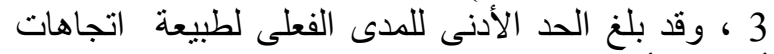
أرباب الأسر المبحوثين نحو التعليم الفنى الصناعى للاعى اجمالا

15 درجة وحده الأعلى 28 درجة.

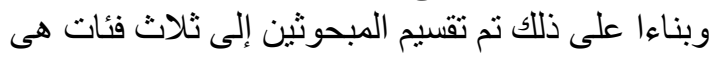

$$
\text { اتجاه منوسط (19 اتجفاه من (15 - } 18 \text { - } 18 \text { ) درجة درجة }
$$$$
\text { (الأسئلة من 20-18) إستمارة (28) درنتيان }
$$

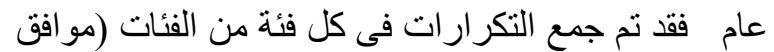

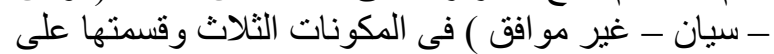

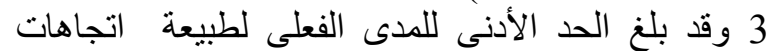

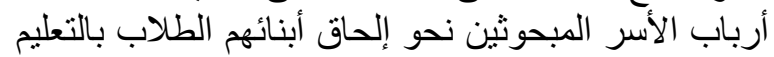

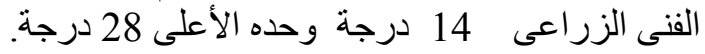

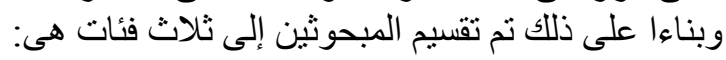

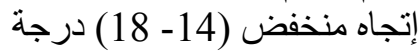

إتجاه منوسط (19- 23 (14- 18) درجة درجة إنجاه مرتفع ( 24- 28 ) درجة دربة

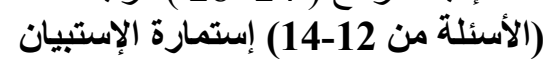

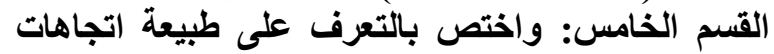

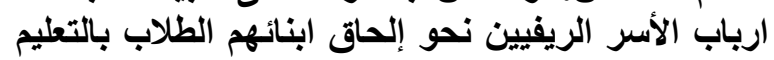

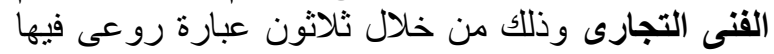

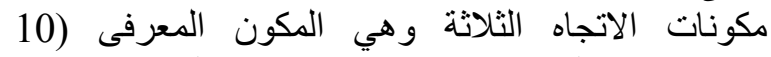

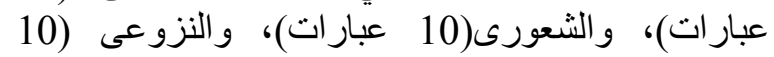

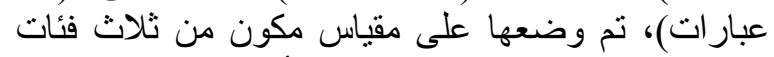

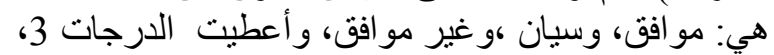
وال2، و 1 في حالة العبار ات الايجابية، و 1 و 2 و 3 في حالة الإنة

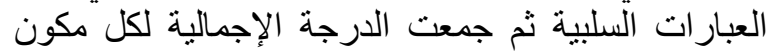
لتعبر عن درجة المكون في الاتجاه وذللك على النحو الإلية لكل

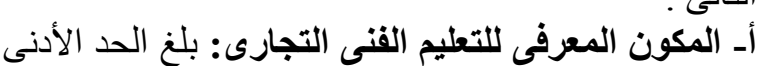

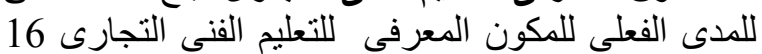

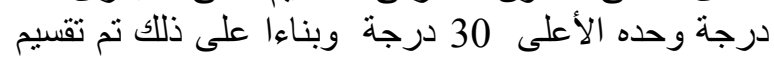
المبحوثين إلى ثناث فئات هى :

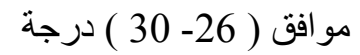
سيان (21- 25 ) درجة غير مو افق( 16 - 20 (20 ) درجة

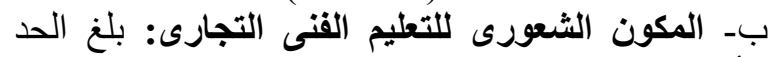

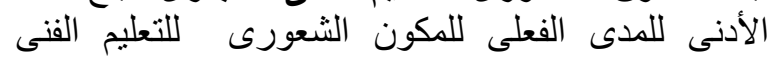

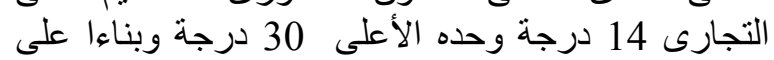

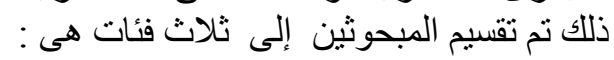
موافق (26- 30 ) درجة سيان ( 19 - 25 ) درجة (30 درجة غير مو افق(14-18) درجة

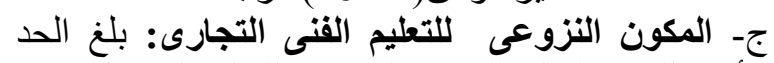

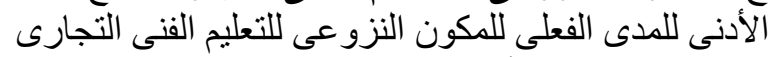

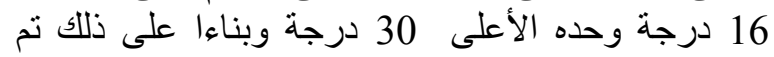

$$
\begin{aligned}
& \text { تقسيم المبحوثين إلى ثلاثل فئات هيى : }
\end{aligned}
$$

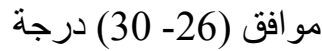

$$
\begin{aligned}
& \text { سيان (21-25) درجة درجة } \\
& \text { غير موافق (16-20) درجة درجة }
\end{aligned}
$$

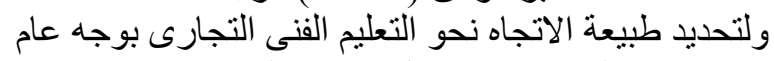

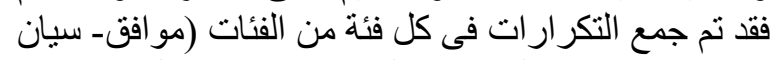

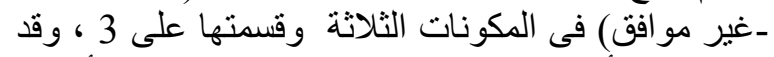

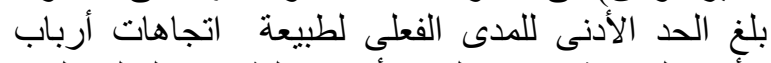

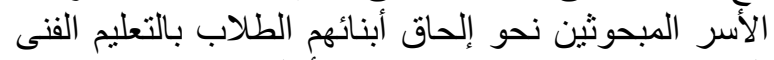

التجارى إجمالا 15 درجة وحده الأعلى النيل 30 درجة. وبناءا على ذلك تم تقسيم المبحوثين إلى ثنلاث فئات هـى : 


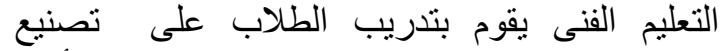

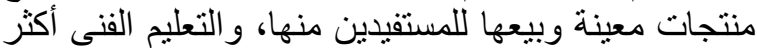

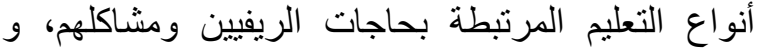

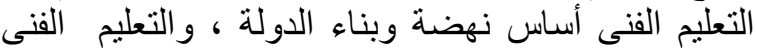

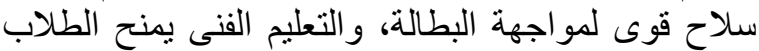
ثقة كبيرة ودرجة عالية فى الإعتماد على النفس والتعليم

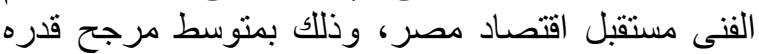
2.9 درجات من 4 نتا ذللك وفى المرنبة التاسعة: التعليم

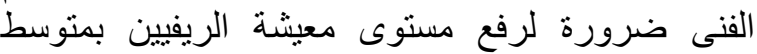
مرجح قدره 2.7 درجة ، تلا ذلك وفى المرتبتين العاثرة

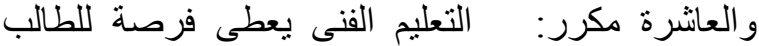
للحصول على وظيفة فى سوق العمل ، و التعليم الفنى يمنح

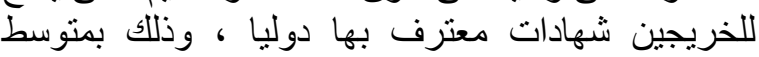

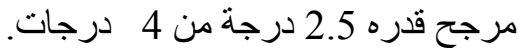

هذا وقد بلغ المتوسط المرجح العام 2.8 درجة درنة 4 درن 4

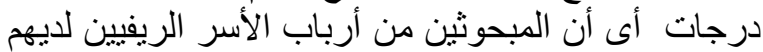

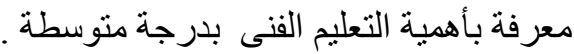

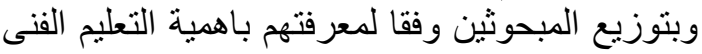

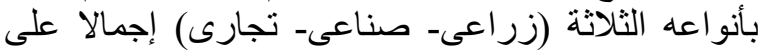

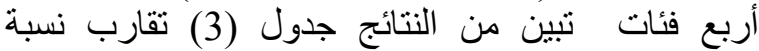
المبحوثين فى فئتى المعرفة المرتفعة والمن المنخفضة بأهمية

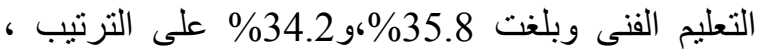
يليها المبحوثون فى فئة المعرفة المتوسطة بنسبة 27.5\% وأن أقل نسبة منهم (2.5\%)ليس لديهم معرفة بأهمية التعليم الفنى.

ثالثا: الأسباب التى تشجع أرباب الأسر المبحوثين على التى

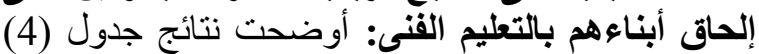

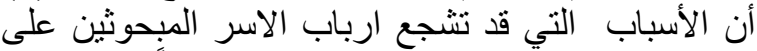
إلحاق أبنائهم بالتعليم الفنى يمكن ترنيبها تنتاز لياً وفقا لأهمية كل سبب من هذه الأسباب كما يلى إنى - جاء في المرتبتين: الأولى، والأولى هذه مكرد الألى السببين

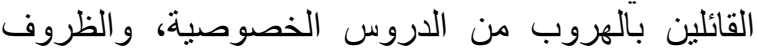
الإجتماعية ، وبلغ المتوسط المرجح لأهمية هذين السببين

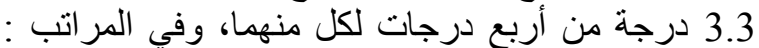

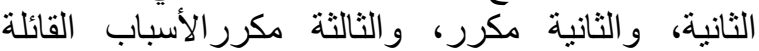

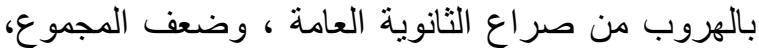

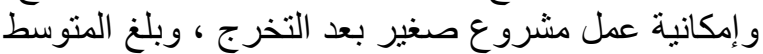

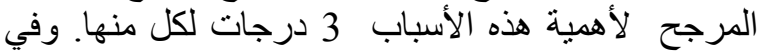
المرتبتين : الرابعة والرابعة مكرر جاء السببين القائلين بالمنافسة مع الزملاء فى مرحلة الثانوية العامة، والتهاء والتعليم الفنى غير مكلف بمتوسط مرجح قدره

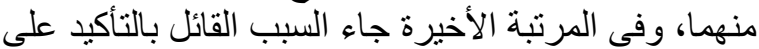
أن التعليم الفنى لا يقل أهمية عن التعليم العام بمتوسط

$$
\text { مرجح قدره } 2.7 \text { درجة. }
$$

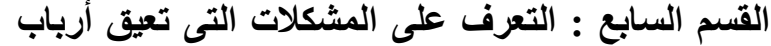

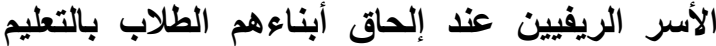

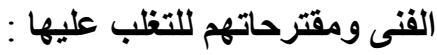

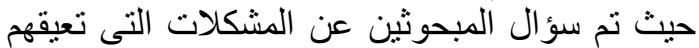

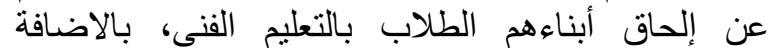

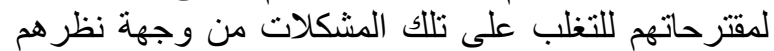

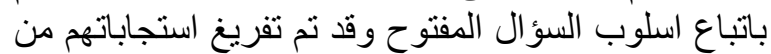

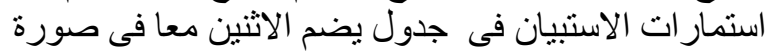
اعداد ونسب مئوية. (السؤال رقم 21) إستمارة الإستبيان

\section{3. النتائج ومناقشتهها}

أولا: وصف عينة البحث من أرباب الأسر المبحوثين أوضحت النتائج (جدول 1) أن منوال سن الند المبحوثنين

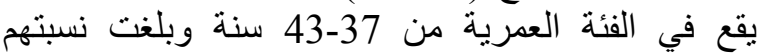

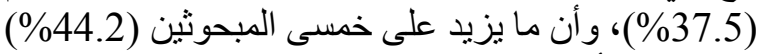

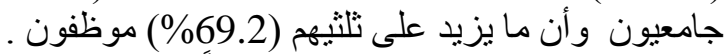

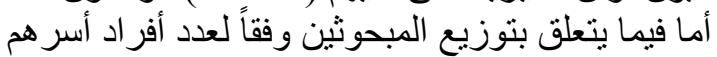
فقد أوضحت النتائج أن الغالبية العظمى من المبحتين المبحوثين

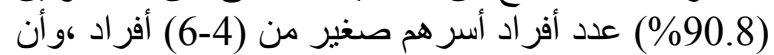

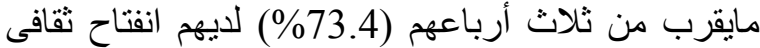

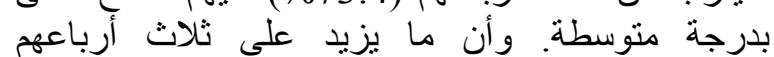

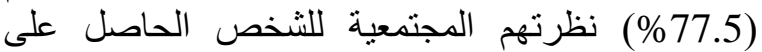

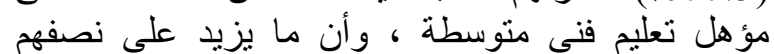

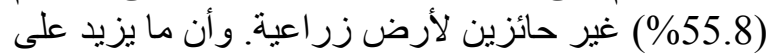
خمسى المبحوثين (42.5\%) بقعون في فئة الدخل الثهري

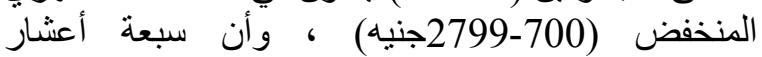
المبحوثين (70\%) حالة مسكنهم متوسطة.

ثانيا : تحديد معرفة أرباب الأسر المبحوثين باهمية التعليم

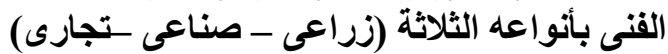

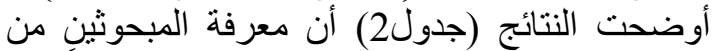
أرباب الأسر بأهمية التعليم الفنى يمكن ترتيبها تنازلياً وفياً

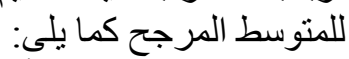
جاء في المراتب : الأولى والأولى مكررو الثانية مكرر

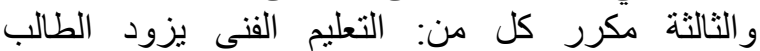

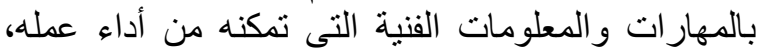

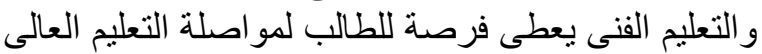

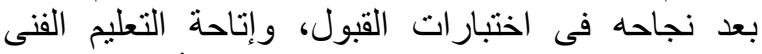
فرصة العمل من المنزل للإناث خاصة فئ أعمال أعمال الحياكة (التطريز - صناعة مفروشات المنازل) ، و مساعدة التعليم الفنى للخريج على عمل مشروع صغير يحقق لله دخل سنوى و ذللك بمتوسط مرجح قدره 3 درجات من 4 تنلاهيا

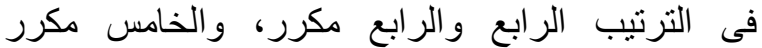

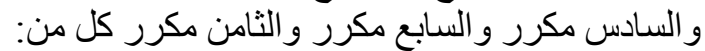




\begin{tabular}{|c|c|c|c|c|c|}
\hline \multicolumn{6}{|c|}{ جدول ( 1 ): توزيع المبحوثين وفقًا لمتغيراتهم المستقلة المدروسة. } \\
\hline$\%$ & عدد & المتغيرات المستقلة المدروسة & $\%$ & ع عدد & المتغيرات المستقلة المدروسة \\
\hline \multirow[b]{3}{*}{8.3} & \multirow[b]{3}{*}{10} & 6-النظرة المجتمعية للشخص الحاصل على مؤهل تعليم فنى & \multirow[b]{2}{*}{37.5} & \multirow[b]{2}{*}{45} & \multirow{2}{*}{ 1- السن: } \\
\hline & & & & & \\
\hline & & نظرة متلنية (10-9) درجات & 30.8 & 37 & 44- 51 سنة \\
\hline 77.5 & 93 & نظرة متوسطة (13-11) درجة & 28.3 & 34 & 52 - 58 \\
\hline 14.2 & 17 & نظرة مرتفعة (15-14) درجة & \multirow{2}{*}{3.4} & \multirow{2}{*}{$\begin{array}{c}4 \\
120\end{array}$} & 65-59 65نة \\
\hline \multirow[t]{2}{*}{100} & 120 & المجموع & & & 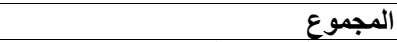 \\
\hline & & 7- مساحة الحيازة الزراعية بالقير اط & & & \multirow{7}{*}{ 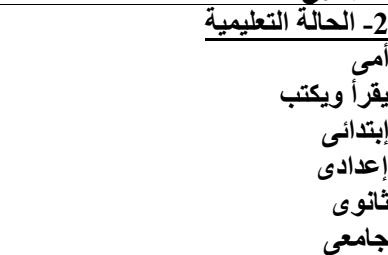 } \\
\hline 55.8 & 67 & غير مبين ** * & 5.0 & 6 & \\
\hline 21.7 & 26 & حيازة صغيرة(5-19) قيراط & 10.0 & 12 & \\
\hline 15.0 & 18 & حيازة متوسطة (20-35) قيراط & 2.5 & 3 & \\
\hline \multirow[t]{3}{*}{7.5} & \multirow[t]{3}{*}{9} & \multirow[t]{3}{*}{ حيازة كبيرة (36-50) قيراط } & 2.5 & 3 & \\
\hline & & & 35.8 & 43 & \\
\hline & & & 44.2 & 53 & \\
\hline \multirow[t]{2}{*}{100} & 120 & المجموع & \multirow[t]{2}{*}{100} & \multirow[t]{2}{*}{120} & \multirow{8}{*}{ 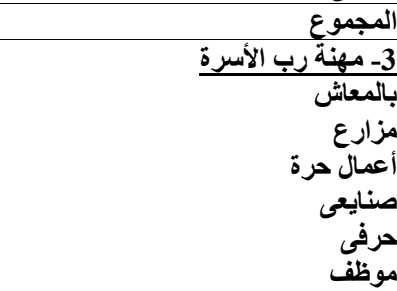 } \\
\hline & & 8ـ الاخل الأسرى الشهرى & & & \\
\hline 17.5 & 21 & غير مبين ** & 1.7 & 2 & \\
\hline 42.5 & 51 & دخل منخفض (700-2799)جنيه & 8.3 & 10 & \\
\hline 35.0 & 42 & دخل متوسط (2800-4899)جنيه & 3.3 & 4 & \\
\hline \multirow[t]{3}{*}{5.0} & \multirow[t]{3}{*}{6} & دخل مرتفع (4900-7000)جنيه & 14.2 & 17 & \\
\hline & & & 3.3 & 4 & \\
\hline & & & 69.2 & 83 & \\
\hline \multirow[t]{2}{*}{100} & 120 & المجموع & 100 & 120 & المجموع \\
\hline & & 9- حالةّ المسكن & \multirow{4}{*}{$\begin{array}{c}90.8 \\
7.5 \\
1.7\end{array}$} & \multirow{4}{*}{$\begin{array}{c}109 \\
9 \\
2\end{array}$} & 4- عدد أفرَراد الأسرة \\
\hline \multirow{7}{*}{$\begin{array}{c}28.3 \\
70 \\
1.7 \\
\end{array}$} & 34 & رديئة (15-15) درجة & & & أَسرة قليلة العدد (4-6) أفراد \\
\hline & 84 & متوسطة (25-20) درجة & & & أسرة متوسطة العدد (7-7) أفراد \\
\hline & 2 & جيدة (30-26) درجة & & & أسرة كثيرة العدد (13-11) فرد \\
\hline & & & & & 5- الانفتاح الثقافي \\
\hline & & & 3.3 & 4 & يحة منخفضة (6-11) درجة \\
\hline & & & 73.4 & 88 & انفتاح بلرجة متوسطة (18-12) درجة \\
\hline & & & 23.3 & 28 & انفتاح بدرجة مرتفعة(19-24) درجة \\
\hline
\end{tabular}

\begin{tabular}{|c|c|c|c|c|c|c|c|c|c|c|}
\hline \multirow{2}{*}{ 司: } & \multirow{2}{*}{ المترجط } & \multicolumn{2}{|c|}{ بلرجة مرتفعة } & \multicolumn{2}{|c|}{ بلرجة متوسطة } & \multicolumn{2}{|c|}{ بلرجة منخفضة } & \multicolumn{2}{|c|}{ لا يعرف بعن } & \multirow{2}{*}{ 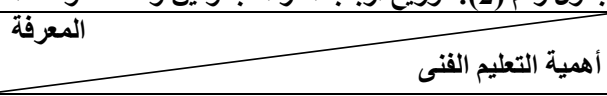 } \\
\hline & & $\%$ & عدد & $\%$ & عدد & $\%$ & عدد & $\%$ & عدد & \\
\hline 1 & 3 & 37.5 & 45 & 29.2 & 35 & 29.2 & 35 & 4.1 & 5 & 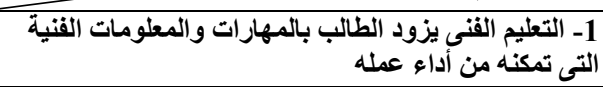 \\
\hline 10 & 2.5 & 18.3 & 22 & 24.2 & 29 & 50.8 & 61 & 6.7 & 8 & في سوق التعليم الفنى يعطى فرصة للطالب للحصول على وظيفة \\
\hline 1 & 3 & 35.0 & 42 & 40.9 & 49 & 18.3 & 22 & 5.8 & 7 & بعد نجاحهة في اختبارات القبولة للطالب لمواصلة التعليم العالى \\
\hline 4 & 2.9 & 35.8 & 43 & 25.0 & 30 & 32.5 & 39 & 6.7 & 8 & 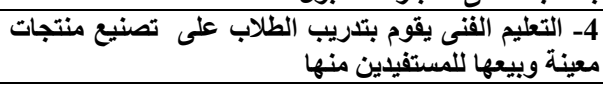 \\
\hline 9 & 2.7 & 25.8 & 31 & 28.4 & 34 & 38.3 & 46 & 7.5 & 9 & 5- التعليم الفنى ضرورة لرفع مستوى معيثة الريفيين \\
\hline P4 & 2.9 & 40.9 & 49 & 21.6 & 26 & 32.5 & 39 & 5.0 & 6 & 6- التعليم الفنى أكثر أنواع التعليم المرتبطة بحاجات \\
\hline 55 & 2.9 & 39.2 & 47 & 17.5 & 21 & 34.2 & 41 & 9.1 & 11 & 7- التعليم الفنى أساس نهضة وبناء الدولة \\
\hline 10 & 2.5 & 27.5 & 33 & 10.8 & 13 & 41.7 & 50 & 20.0 & 24 & 8- التعليم الفنى يمنح للخريجين شهادات معترف بها دوليا \\
\hline 6 & 2.9 & 39.2 & 47 & 18.3 & 22 & 36.7 & 44 & 5.8 & 7 & 9- التعليم الفنى سلاح قوى لمواجهة البطالة \\
\hline 2 & 3 & 43.3 & 52 & 23.4 & 28 & 30.0 & 36 & 3.3 & 4 & 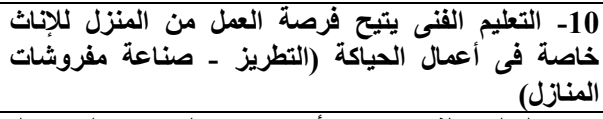 \\
\hline م3 & 3 & 42.5 & 51 & 22.5 & 27 & 32.5 & 39 & 2.5 & 3 & مشروع صغير يحقق لَه دخل سنوى أنساعد الخريج على عمل \\
\hline م7 & 2.9 & 36.7 & 44 & 15.8 & 19 & 44.2 & 53 & 3.3 & 4 & الإعتماد على النفسي يمنح الطلاب ثقة كبيرة ودرجة عالية فى \\
\hline م8 & 2.9 & 39.2 & 47 & 17.5 & 21 & 38.3 & 46 & 5.0 & 6 & 13- التعليم الفنى مستقبل اقتصاد مصر \\
\hline & 2.8 & العام & المرجح & المتوسط & & & & & & \\
\hline
\end{tabular}




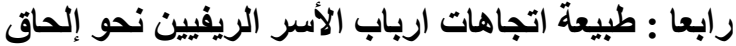

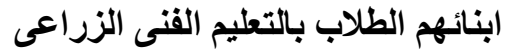

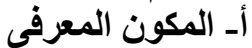

أوضحت نتائج جدول (6) أن ثلاث أرباع المبحوثين

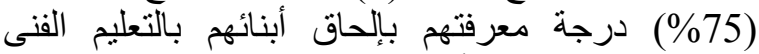

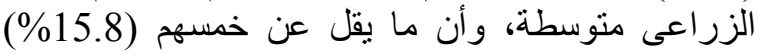

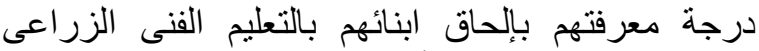
منخفضة، في حين كانت أقل نسبة من المبحوثين (9.2\%)
جدول (3): توزيع المبحوثين وفقًا لمعرفتهم بأهمية النعليم

الفنى.

\begin{tabular}{|c|c|c|}
\hline$\%$ & عدد & فئات المعرفة \\
\hline 2.5 & 3 & لا يعرف (22-13) درجة \\
\hline 34.2 & 41 & منخفضة (32-23) درجة \\
\hline 27.5 & 33 & متوسطة (43-33) درجة \\
\hline 35.8 & 43 & مرتفعة (42-52) درجة \\
\hline 100 & 120 & الإجمالى \\
\hline
\end{tabular}

جدول (4): توزيع أرباب أسر المبحوثين وفقًا للمتوسط المرجح للأهمية النسبية للأسباب التى تشجعهم على الحاق ابنائهم بالتعليم الفنى.

\begin{tabular}{|c|c|c|c|c|c|c|c|c|c|c|}
\hline & \multirow{2}{*}{ المترجط } & \multicolumn{2}{|c|}{ 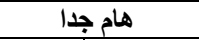 } & \multicolumn{2}{|c|}{ هام } & \multicolumn{2}{|c|}{ 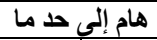 } & \multicolumn{2}{|c|}{ غير هام } & \multirow{2}{*}{ الأسباب الاهمية النسبية } \\
\hline & & $\%$ & عدد & $\%$ & عدد & $\%$ & عدد & $\%$ & عدد & \\
\hline 2 & 3 & 51.7 & 62 & $\mathbf{1 0 . 0}$ & 12 & 32.5 & 39 & 5.8 & 7 & 1- الهزروب من صر اع الثانوية العامة \\
\hline 1 & 3.3 & 60.0 & 72 & 10.8 & 13 & 24.2 & 29 & 5.0 & 6 & 2- الهروب من الدروس الخصوصية \\
\hline 4 & 2.9 & 37.5 & 45 & 16.7 & 20 & 25.8 & 31 & 20.0 & 24 & 3ـ المنافسة مع الزملاء فى مرحلة الثانوية \\
\hline 5 & 2.7 & 34.2 & 41 & 22.5 & 27 & 25.0 & 30 & 18.3 & 22 & 4- التعليم التعام على أن التعليم الفنى لا يقل أهمية عن \\
\hline 4 & 2.9 & 44.2 & 53 & 18.3 & 22 & 24.2 & 29 & 13.3 & 16 & 5ـ التعليم الفنى غير مكلف \\
\hline 2 & 3 & 54.1 & 49 & 22.5 & 27 & 19.2 & 23 & 4.2 & 5 & 6- ضعف المجموع \\
\hline 1 & 3.3 & 59.1 & 71 & 17.5 & 21 & 15.0 & 18 & 8.4 & 10 & 7- الظروف الإجتماعية \\
\hline م3 & 3 & 46.7 & 56 & 20.8 & 25 & 20.0 & 24 & 12.5 & 15 & 8- إمكانية عمل مشروع صغير بعد التخرج \\
\hline & 3 & 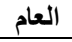 & المرجح & المتوسط & & & & & & \\
\hline
\end{tabular}

درجة معرفتهم بإلحاق ابنائهم بالتعليم الفنى الزراعى مر تفعة. وقد يرجع ذلك إلي ارتفاع درجة تعرض أرباب الأسر

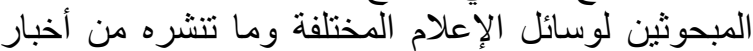

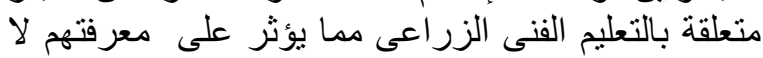

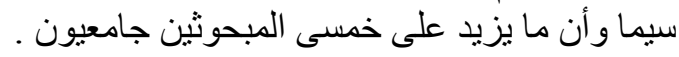

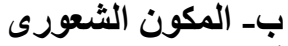

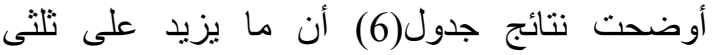
المبحوثين(68.3\%) بقعون فى فئة المستوى المتوسط للمكون الشعورى ، وأن ما يقرب من ربعهي (22.5\%)

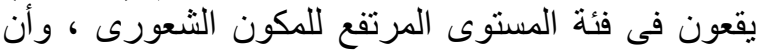
أقل نسبة منهم (9.2\%) يقعون فى فئة المستوى المنخفض

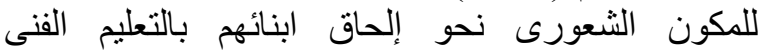

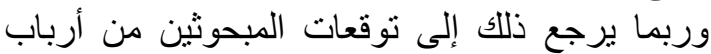

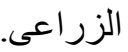

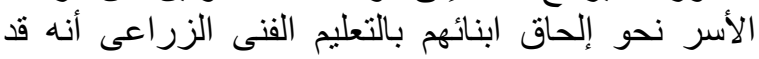

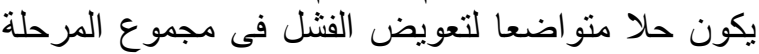

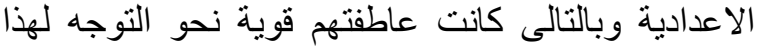

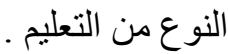

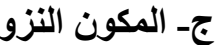

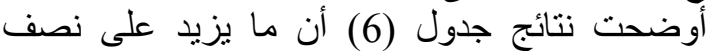
المبحوثين (53.3\%) يقعون في فئة المستوى المتوسط

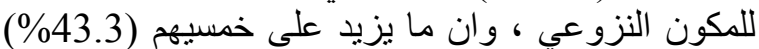

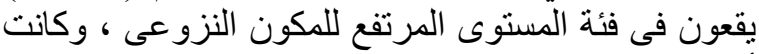

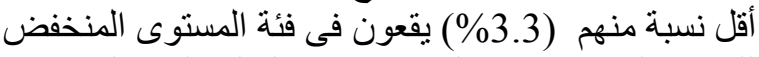

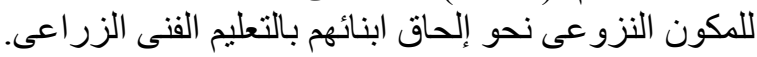

ـهذا وقد بلغ المتوسط المرجح العام للأهمية النسبية للأسباب التى تشجع أرباب الأسر المبحوثين على إلحاق القئ

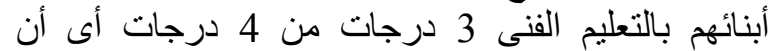
المبحوثين يرون أن هذه الأسباب المذكورة دهاتة

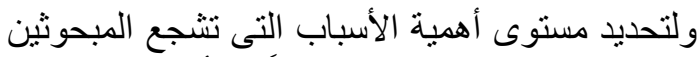

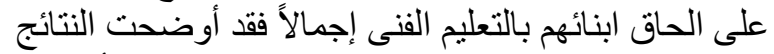
(جدول 5) نقارب نسبتى المبحوثين الذين يرون أن هذه باني

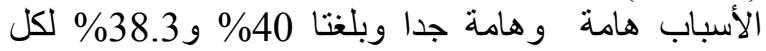

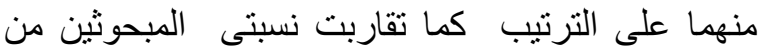

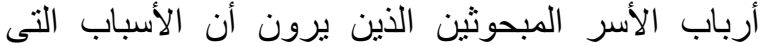
تشجعهم على إلحاق أبنائهم بالتعليم الفنى هامة إلى الى حد ماء

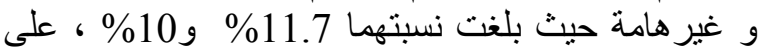
الترنيب.

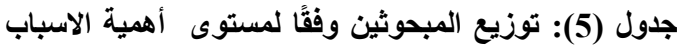

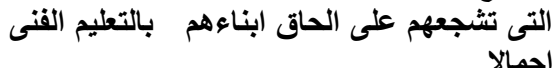

\begin{tabular}{|c|c|c|}
\hline$\%$ & عدد & مستوى الهية الاسباب اجمالا \\
\hline 10.0 & 12 & غير هام (10 -14) درجة \\
\hline 11.7 & 14 & هام الى حد ما (15 - 19) درجة \\
\hline 40.0 & 48 & هام (20- 27) درجة \\
\hline 38.3 & 46 & هام جدا ( 28- 32) درجة \\
\hline 100 & 120 & الإجمالى \\
\hline
\end{tabular}




\begin{tabular}{|c|c|c|c|c|c|c|c|c|c|c|c|}
\hline$\%$ & عدد & الاتجاه الاجمالي & $\%$ & عدد ( عد & المكون النزوعي & $\%$ & عدد & المكون الشعوري & $\%$ & | عدد & المكون المعرفي \\
\hline 10 & 12 & منخفض (14-18) & 3.3 & 4 & منخفض (16-20) & 9.2 & 11 & منخفض (14-18) & 15.8 & 19 & منخفض (14-17) \\
\hline 65 & 78 & متوسط (19-23) & $\overline{53.4}$ & 64 & متوسط & 68.3 & 82 & متوسط (19-23) & 75 & \begin{tabular}{|l|}
90 \\
\end{tabular} & متوسط (18-22) \\
\hline 25 & 30 & مرتفع (24-28) & 43.3 & 52 & $(30-$ & 22.5 & 27 & مرتفع (24-28) & 9.2 & \begin{tabular}{|l|}
11 \\
\end{tabular} & مرتفع (23-26) \\
\hline 100 & 120 & اللمجموع & 100 & 120 & المجمــوع & 100 & 120 & المجمـــوع & 100 & 120 & المجمــوع \\
\hline
\end{tabular}

أخماس المبحوثين من أرباب الأسر (60.8\%) لديهر

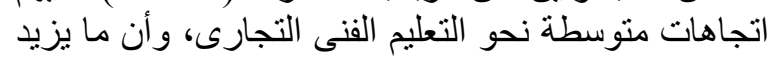

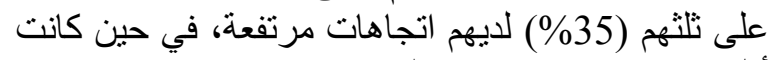

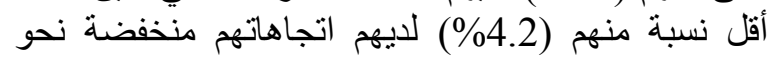

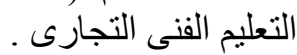

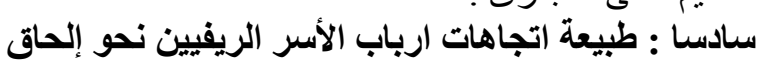

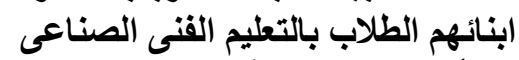

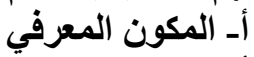

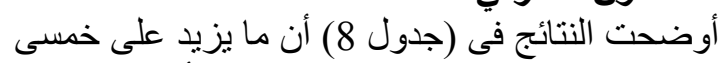
المبحوثين (44.2\%) درجة معر فتهم بإلحاق أبنائهم بالتعليم

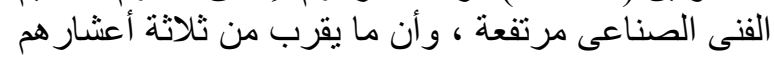

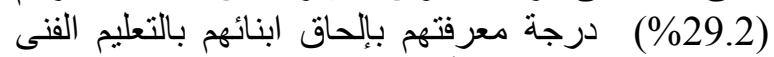

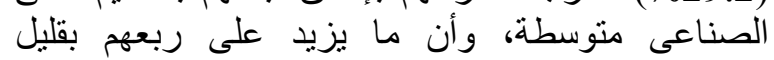
(26.6\%) درجة معرفتهم بإلحاق ابنائهم بالتعليم الفنى رئى

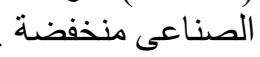

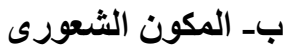

أوضحت النتائج فى (جدول8) أندون أن ما يقرب من ثلاث

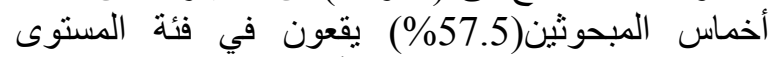

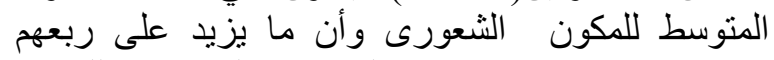

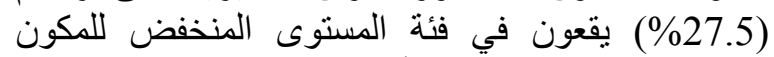

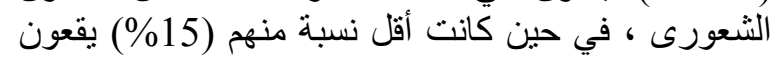

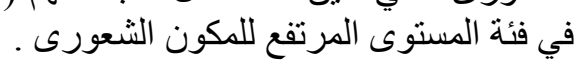

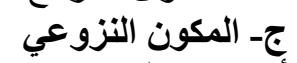

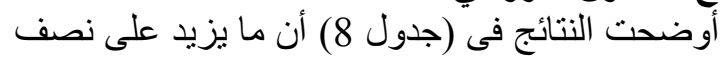

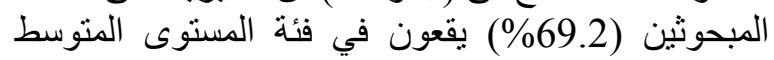

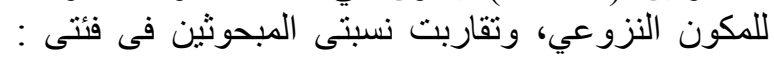

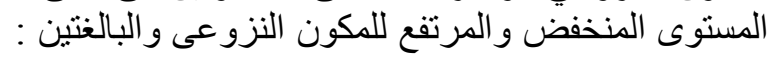

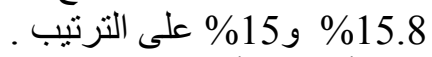
اتجاه أرباب الأسر المبحوثين نحو إلحاث أبنائهم بالتعليم

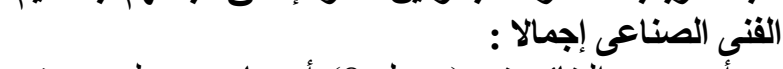

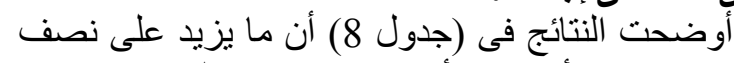
المبحوثين من أرباب الأسر (

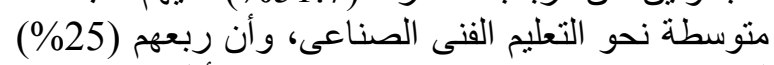
لايهم اتجاهات مرتفعة، في حين كانت التهات أقل نسبة منهم (23.3\%) لديهم اتجاهاتهم منخفضنة نحو التعليم الفنى

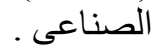
سابعا : تحديد العلاقة بين المتغيرات المستقلة المدروسة

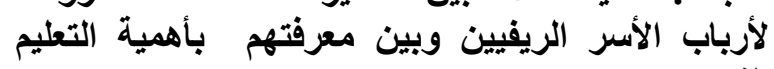

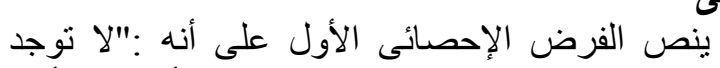
علاقة بين المتغيرات المستقلة المدروسة الإنى لأرباب الأسر

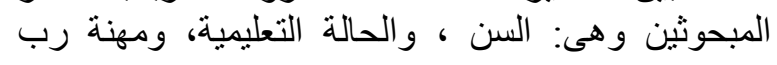

وقد يرجع ذلك إلى اهتمام الدولة بالتعليم الفنى وما تبعه

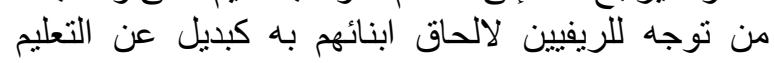

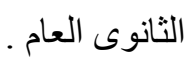

اتجاه أرباب الأسر المبحوثين نحو إلحاق أبنائهم بالتعليم القنى الزراعى إجمالا.

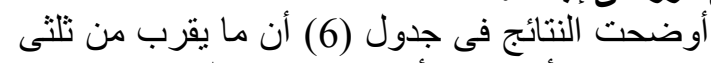

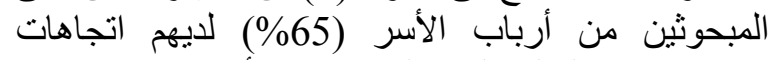

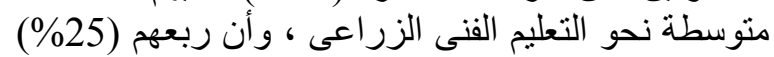
لايهم اتجاهات مرتفعة، في حين التهات كانت أقل نسبة منهم (10)

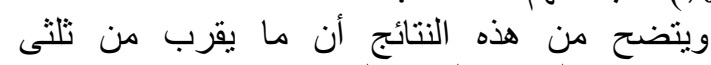

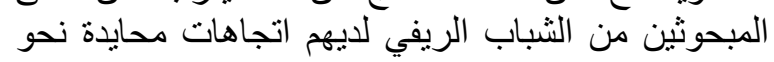

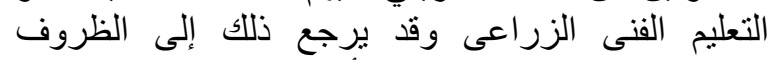

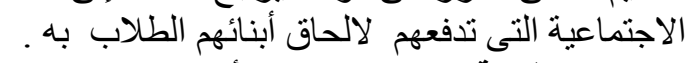

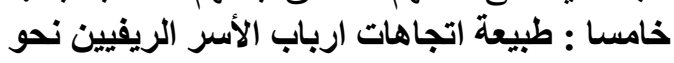

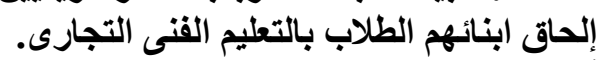
أـ المكون المعرفي الطهي

أوضحت النتائج فى جدول (7) (7) أن الغالبية العظمى من

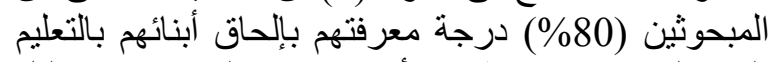

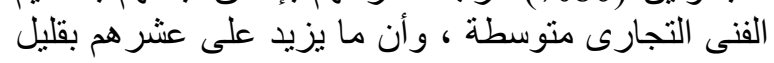

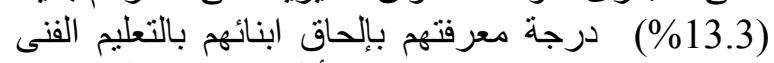

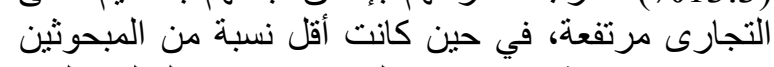

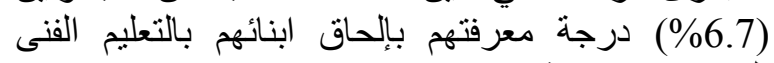
التجارى منخفضة . بـ المكون الثعوري

أوضحت النتائج فى جدول الثوري (7) أن نصف المبحوثين

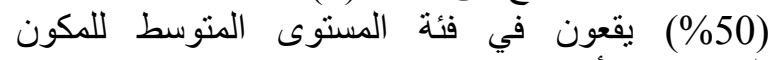

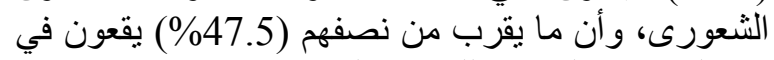

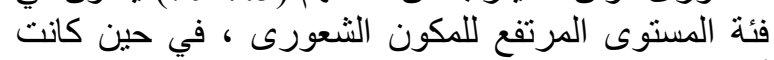

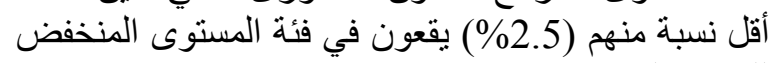

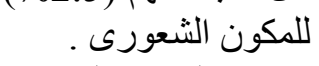
ج- المكون النزوعي

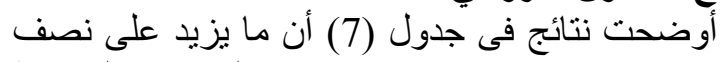

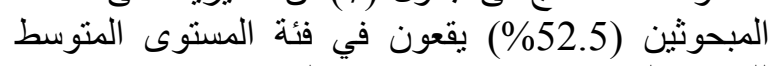

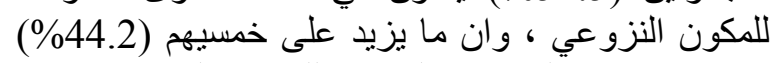

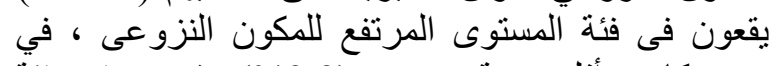

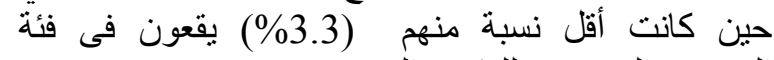

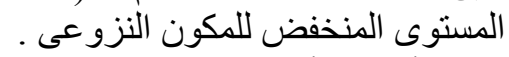
اتجاه أرباب الأسر المبحوثين نحو إلحاثَ أبنائهم بالتطليم الفنى التجارى إجمالا الأبرال أوضحت النتائج فى جدول (7) أن ما يزيد على ثلاث 
جدول (7) : توزيع المبحوثين وفقا للمكون المعرفي والثعوري والنزوعي والاتجاه الاجمالي نحو إلحاق أبنائهم الطلاب بالتعليم الفنى التجارى.

\begin{tabular}{|c|c|c|c|c|c|c|c|c|c|c|c|}
\hline$\%$ & عدد & الاتجاه الاجمالي & $\%$ & عدد & المكون النزوعي & $\%$ & عدد & المكون الشعوري & $\%$ & عدد & المكون المعرفي \\
\hline 4.2 & 5 & منخفض (19-15) & 3.3 & 4 & منخفض (16-20) & 2.5 & 3 & منخفض (18-14) & 6.7 & 8 & خفض (16-20) \\
\hline 60.8 & 73 & متوسط (25-20) & 52.5 & 63 & متوسط & 50 & 60 & متوسط (19-5 & 80 & 96 & كسط ( \\
\hline 35 & 42 & مرتفع (30-26) & 44.2 & 53 & مرتفع (20-30 & 47.5 & 57 & مرتفع (26-30 & 13.3 & 16 & تفع (30-26) \\
\hline 100 & 120 & |المجموع & 100 & 120 & |المجمــوع & 100 & 120 & المجمــوع & 100 & 120 & 1 \\
\hline
\end{tabular}

\begin{tabular}{|c|c|c|c|c|c|c|c|c|c|c|c|}
\hline$\%$ & عدد & الاتجاه الاجمالي & $\%$ & عدد & المكون النزوعي & $\%$ & عدد ( ع ال & |المكون الثُعوري & $\%$ & عدد & المكون المعرفي \\
\hline 23.3 & 28 & منففض (18-15) & 15.8 & 19 & منخفض (21-18) & 27.5 & 19 & منخفض(18-18) & 26.6 & 32 & منخفض (9-13) \\
\hline 51.7 & 62 & متوسط (19-23) & 69.2 & 83 & متوسط (26-22) & $\mathbf{5 7 . 5}$ & 83 & متوسط (26-22) & 29.2 & 35 & متوسط (19-14) \\
\hline 25 & 30 & مرتفع (28-24 ) & 15 & 18 & مرتفع (30-27) & 15 & 18 & مرتفع (27-30) & 44.2 & 53 & مرتفع (24-20) \\
\hline 100 & 120 & لمجموع & 100 & 120 & لمجمــوع & 100 & 120 & المجمــوع & 100 & 120 & المجمــوع \\
\hline
\end{tabular}

المهنة ، و الحالة التعليمية لأرباب الأسر المبحوثين وبين

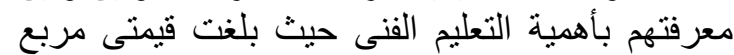

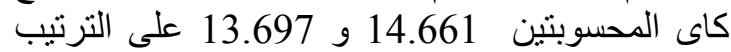

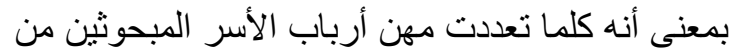
الزراع وأرباب الصناعة والحرفيين (كما تشير النتائج)

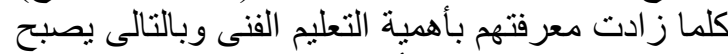
هنالك تفاوت فى توجيه أبنائهم الطلاب لنوفية لنية التعليم

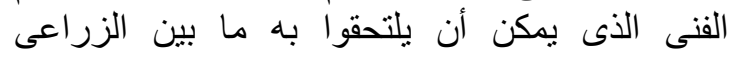

الأسرة، و عدد أفراد الأسرة، والإنفتاح الثقافى ، والنظرة

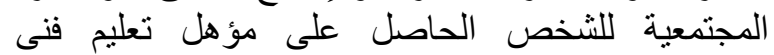

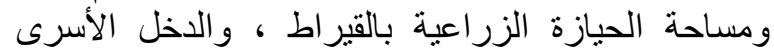

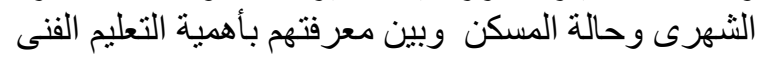

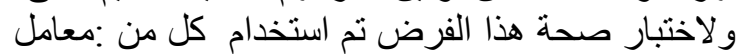
الإرتباط البسيط لبيرسون للمتغيرات ذات الطبيعة المتصلة

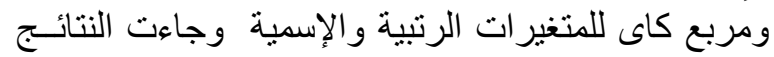

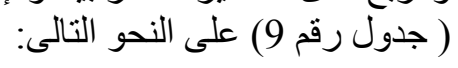

جدول (9): قيم معامل الارتباط البسيط ومربع كاى للعلاقة بين المتغيرات المستقة المدروسة لأرباب الأسر المبحوثين وبين معرفتهم بأهمية

\begin{tabular}{|c|c|c|c|}
\hline & & & التعليم الفنى. \\
\hline قيم مربع كاى & المتغيرات المستقلة المدروسة & قيم معامل الارتباط البسيط & المتفيرات المستقلة المدروسة \\
\hline * 14.661 & مهنة رب الأسرة & $* * 0319$ & عدد أفراد الأسرة \\
\hline *13.697 & الحالة التعليمية & $0 . * 208-$ & الاخل الشهرى الأسرى \\
\hline
\end{tabular}

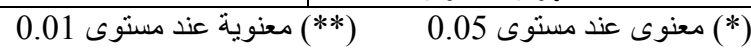

و التجارى و الصناعى. كما أن ارتفاع حالتهم التعليمية مأدية (ما يزيد على خمسيهم حاصلين على مؤهل هلات جامعية )

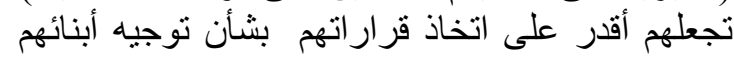

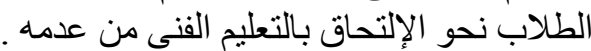

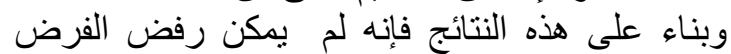

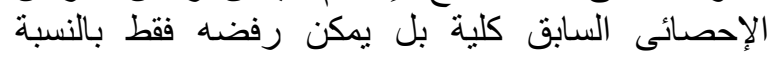

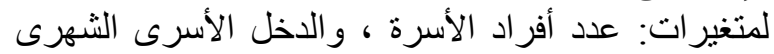

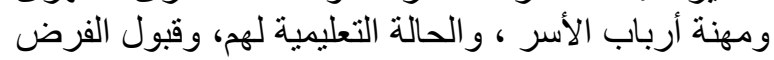

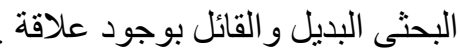

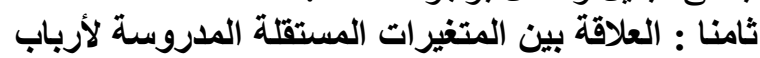

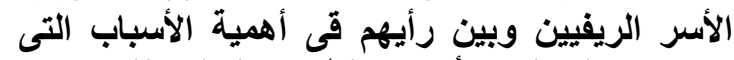

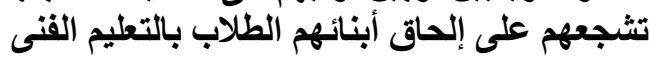

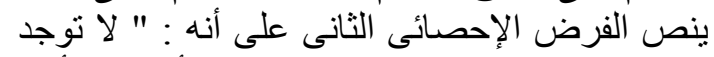

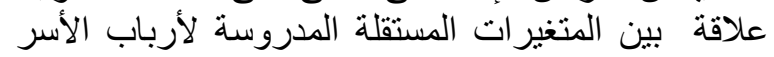

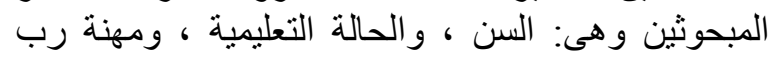

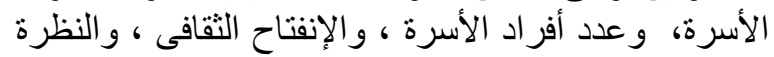

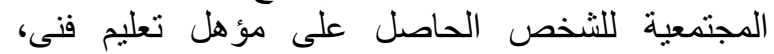

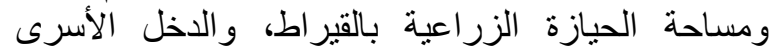

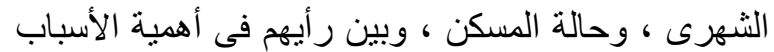

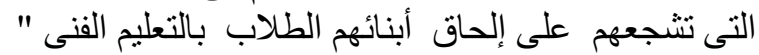

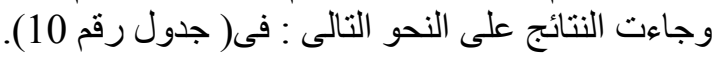

أـ نتائج معامل الإرتباط البسيط لبيرسون

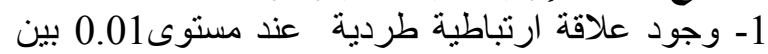

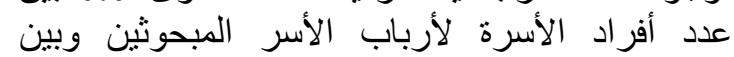

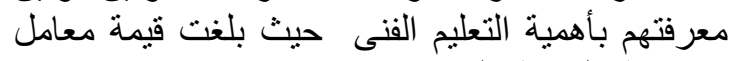

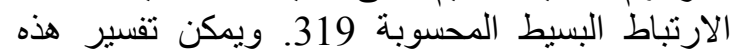

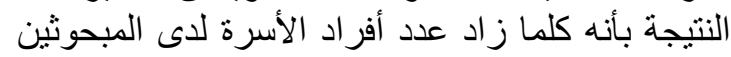

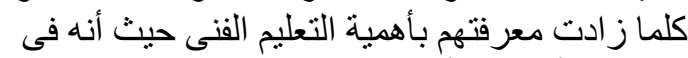

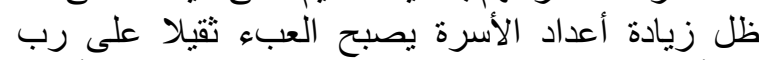

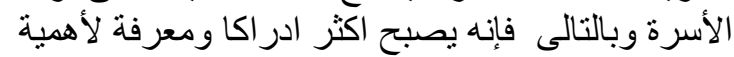

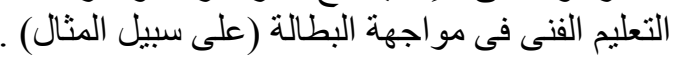

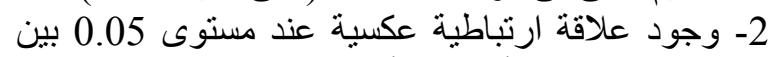

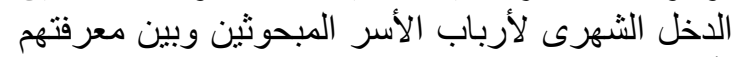

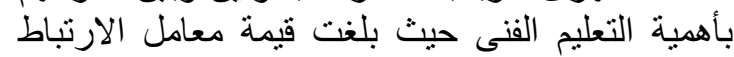

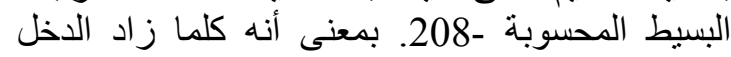

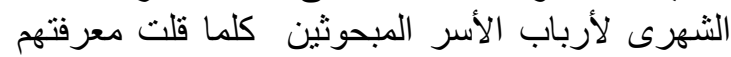

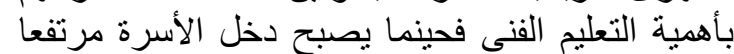
فإن رب الأسرة بالرغم من ذللك لا يفضل الحاق أبنائه

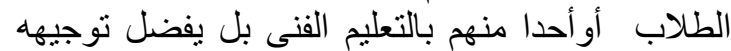

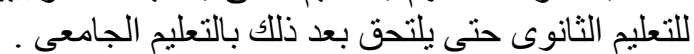

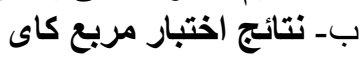
3- وجود علاقة معنوية عند مستوى منار منايع 0.05 بين كل من : 
بالقيراط و الدخل الثهرى، و والانفتاح الثقافى و السن

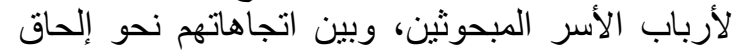

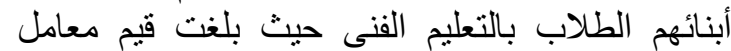

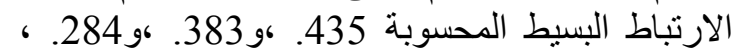

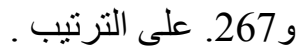

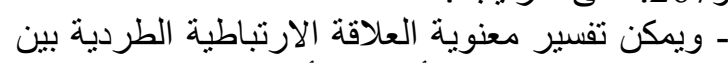
مساحة الحيازة الزر اعية لأرباب الأسر الريفيبين المباطية الطبحوثين بين

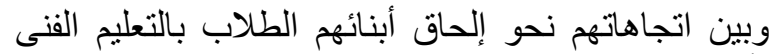

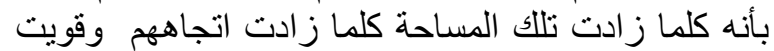

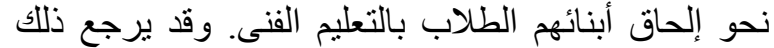

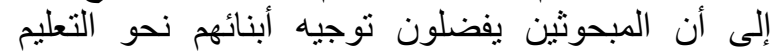

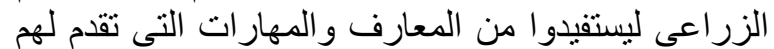

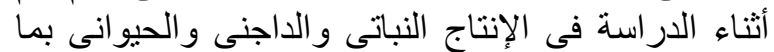

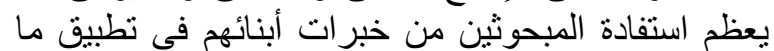

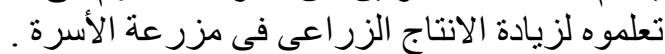

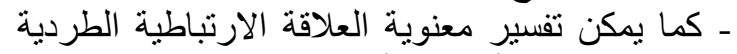

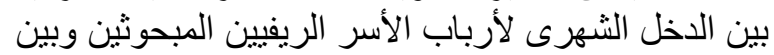

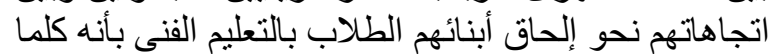

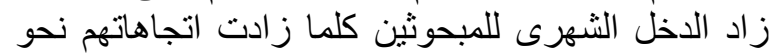

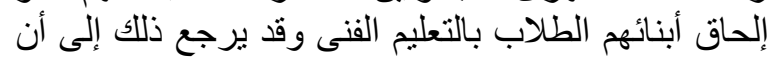

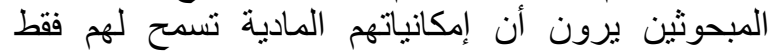

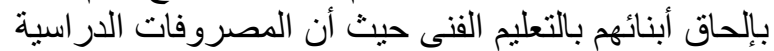
لطالب التعليم الفنى أقل من نظيرنها فلى الفى التعليم الثنانوى

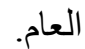

ـ كما يمكن تفسير معنوية العلاقة الارتباطية الطردية

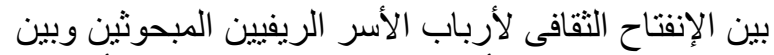

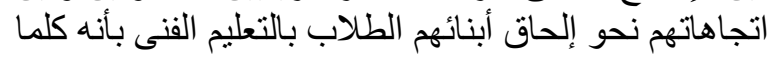

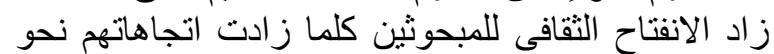
إلحاق أبنائهم الطلاب بالتعلئيم الفنى فمطالعة الأخبار

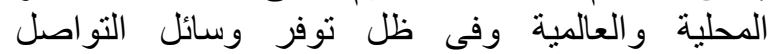

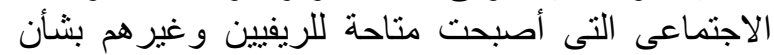

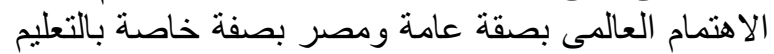

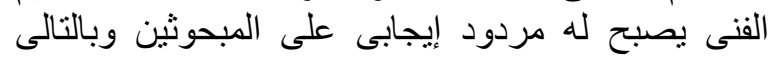

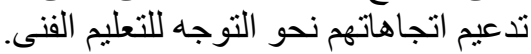

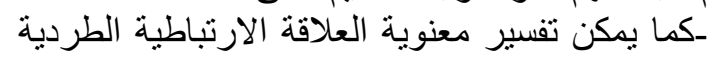

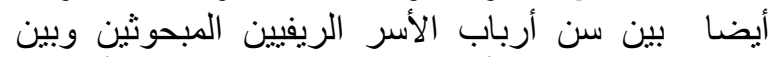

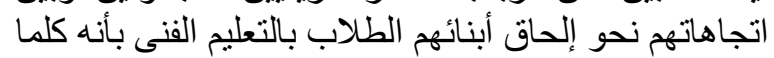

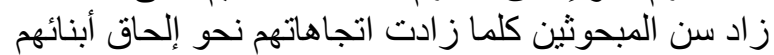

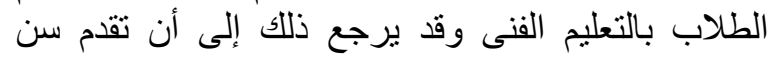

جدول (11): قيم معامل الارتباط البسيط ومربع كاى للعلاقة بين المتغيرات المستقلة المدروسة المبلة الأرباب الأسر المبحوثين وبين التجاهاتهم نحو إلمات المات أبنائهم

\begin{tabular}{|c|c|}
\hline قيم معامل الإرتباط البسيط & المتغيرات المستقلة المدروسة \\
\hline$* .435$ & مساحة الحيازة الزراعية \\
\hline *. 383 & الاخل الأسرى الشهرى \\
\hline$* .284$ & الإنفتاح الثقافى \\
\hline$* .267$ & السن \\
\hline
\end{tabular}

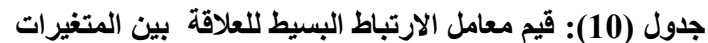

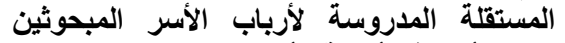

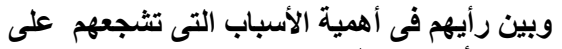
إلحاق أبنائهم الطلاب بابلة التعليم الفنى.

\begin{tabular}{|c|c|}
\hline قيم معامل الإرتباط البسيط & المتغيرات المستقلّة المدروسة \\
\hline$* * .239$ & السن \\
\hline$* * .381-$ & الاخل الأسرى الثهرى \\
\hline
\end{tabular}

(*) معنوية عند مستوى 0.050 .01 (*) معنوية عند مستوى

4- وجود علاقة ارتباطية طردية عند مستوى01010بن بين: سن أرباب الأسر المبحوثين، وبردية عند رأيهن في أهمية

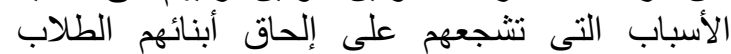

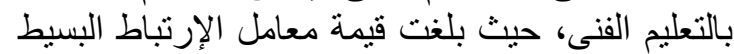

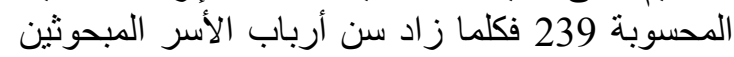

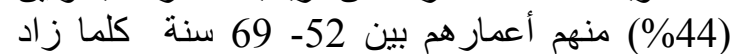

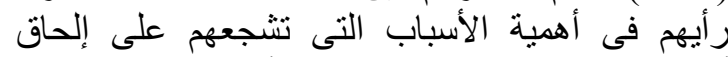

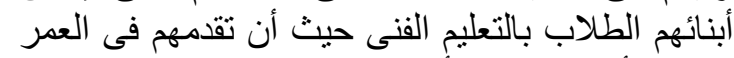

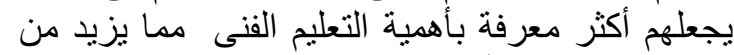

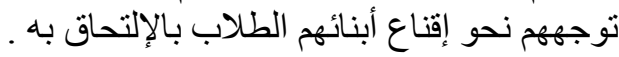

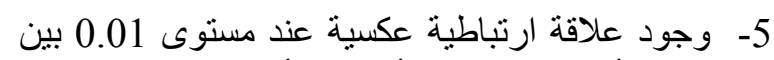

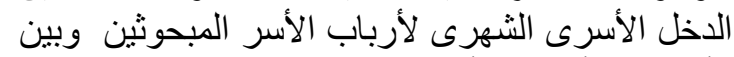

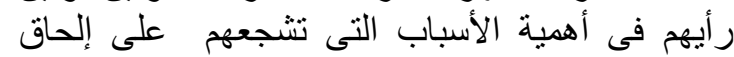

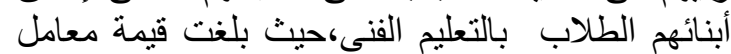

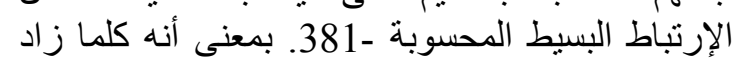
الإخل الأسرى الشهرى لأرباب الأسر المبحوثين كلما

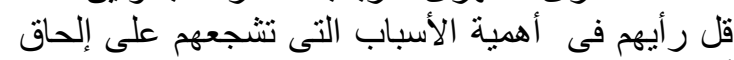

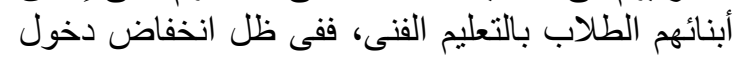

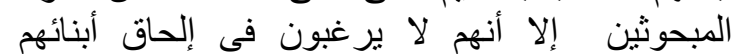

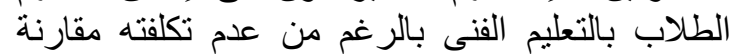

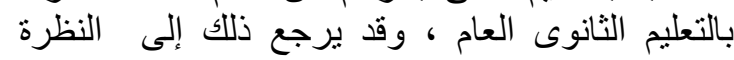

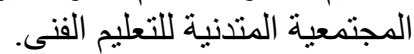

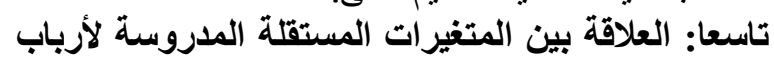

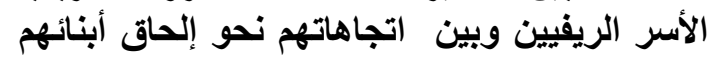
الطلاب بالتعليم الفنى الفين

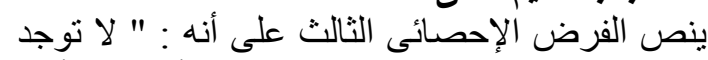

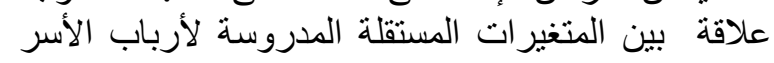

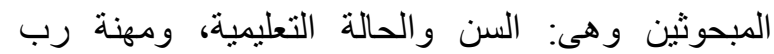
الأسرة، وعدد أفراد الأسرة، والإنفتاح الثقافى، و والنظرة

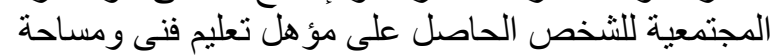

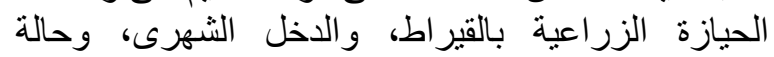

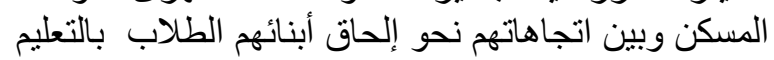
الفنى " وجاعن

وجاءت النتائج على النحو النالى فى : ( جدول رقدم 11 11)

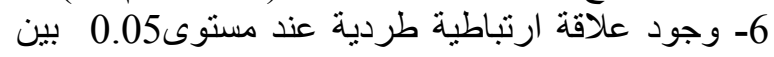

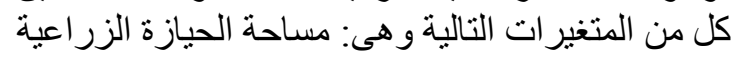


6- جاء فى المرتبة السادسة (رغبة الأهالى فى إلحاق

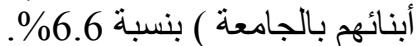

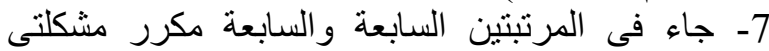

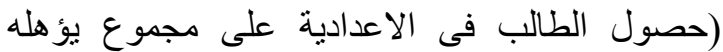
للالتحاق بالثانوى العام) و ( عدم وجود مدرسين مدربين

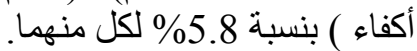

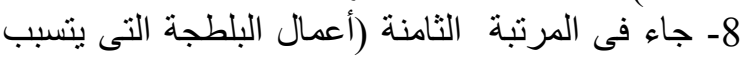
فيها الطلاب نتيجة الاختلاط بالطالبات ) بنسبة 5 5.

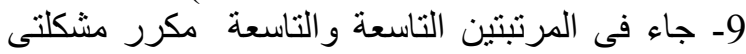

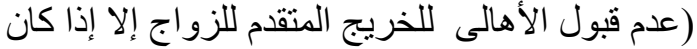
جامعيا ) و(عدم توفر دورات تدريبية لخريجى التعليم

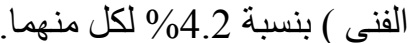
حادى عشر: مقترحات أرباب الأسر المبحوثين للتظلب على المشكلات التى تعيق إلحاق البقاب أبنائهم الطلاب بالتعليم الفنى الفى تصن

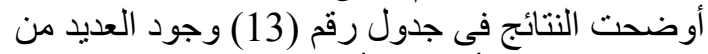

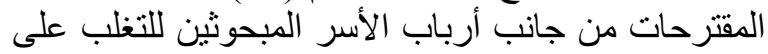

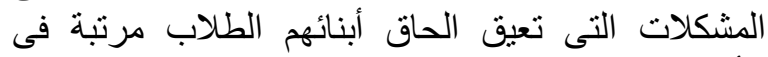

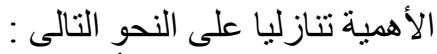
جاء فى المرتبة الأولى إعادة النظر من جانب الني الدولة

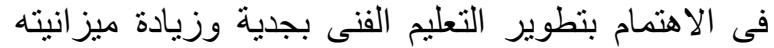
بنسبة (8.3\%)، وفى المرنبة الثنانية جاء نوفير فرص عمل

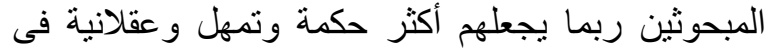

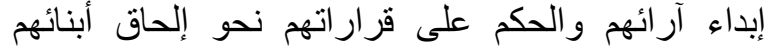

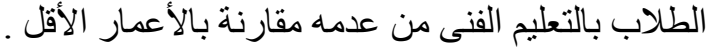
عاشرا : المشكلات التى تعيق ارياب الأسر الريفيين المبحوثين عند إلحاق أبنائهم الطلاب بالتعليم الأبير

القنى

تعددت المشكلات التى تعيق أرباب الأسر الريفيين

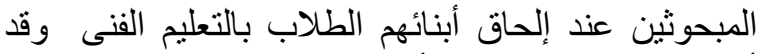

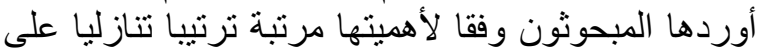

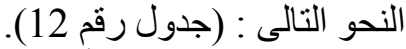
1- جاء فى المرتبة الأولى (ضعف المَف الامكانيات المادية و البشرية بالمدارس الفنية لتدريب الطلاب عمليا) بنسبة الابة الطبانة .\%15

2- جاء فى المرتبة الثنانية (النظرة المجتمعية المتدنية للتعليم

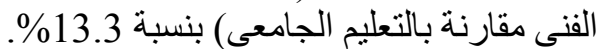
3-جاء فى المرنبة الثالثة (عدم توفر فرص عمل بنسية للخريجين) بنسبة 10\% 4- جاء فى المرنبة الرابعة (التعليم فى مصر منفصل عن

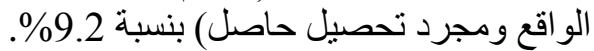

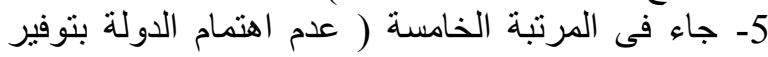
واعتماد ميزانيات كافية لتطوير التعليم الفنى ) بنسبة النية $\% 7.5$

\begin{tabular}{|c|c|c|c|c|}
\hline \multirow{2}{*}{ الترتيب } & & & \multirow[b]{2}{*}{ 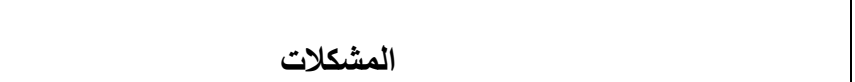 } & \multirow[t]{2}{*}{ م } \\
\hline & $\%$ & عدد & & \\
\hline & 50 & 60 & |غير مبين ** & \\
\hline 1 & 15 & 18 & ضعف الإمكانيات المادية والبثرية بالمدارس الفنية لتدريب الطلاب عمليا & 1 \\
\hline 2 & 13.3 & 16 & |النظرة المجتمعية المتلنية للتعليم الفنى مقارنة بالتعليم الجامعى & 2 \\
\hline 3 & 10 & 12 & عدم توفر فرص عمل للخريجين & 3 \\
\hline 4 & 9.2 & 11 & التعليم الفنى في مصر منفصل عن الواقع ومجرد تحصيل حاصل & 4 \\
\hline 5 & 7.5 & 9 & |عدم اهتمام الدولة بتوفير واعتماد ميزانيات كافية لتطوير التعليم الفنى & $\mathbf{5}$ \\
\hline 6 & 6.6 & 8 & رغبة الأهالى في إلحاق أبنائهم بالجامعة & 6 \\
\hline 7 & 5.8 & 7 & حصول الطالب في الاعدادية على مجموع كبير يؤهله للالتحاق بالثانوى العام & 7 \\
\hline 27 & 5.8 & 7 & علدم وجود مدرسين مدربين أكفاء & 8 \\
\hline 8 & 5 & 6 & اعمال البلطجة التى يتسبب فيها الطلاب نتيجة الاختلاط بالطالبات & 9 \\
\hline 9 & 4.2 & 5 & علدم قبول الأهالى للخريج المتقام للزواج إلا إذا كان جامعيا & 10 \\
\hline 29 & 4.2 & 5 & عدم توفر دورات تدريبية لخريجي التعليم الفني & 11 \\
\hline
\end{tabular}

جذول ( 13 ): توزيع المبحوثين من أرباب الأسر وفقًا لمقترحاتهم للتظلب على المشكلات التى تعيق إلحاق أبنائهم الطلاب بالتعليم الفنى.

\begin{tabular}{|c|c|c|c|c|}
\hline التزتيب & $\%$ & 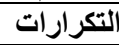 & 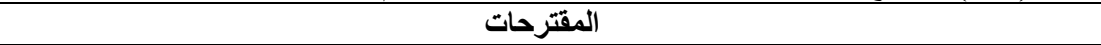 & م \\
\hline 1 & 8.3 & 10 & إعادة النظر من جاتب الدولة فى الاهتمام بتطوير التعليم الفنى بجلية وزيادة ميزانيته & 1 \\
\hline 2 & 7.5 & 9 & اومصيروبية عمل للخريجين فى صورة مشروعات تدر عليهم دخل وتيسير اجراءاتها بدون وساطة & 2 \\
\hline 3 & 4.2 & 5 & تغيير وتعديل المناهج الدراسية القايمة وتحديثها بما يتناسب مع سوق العمل & 3 \\
\hline 4 & 2.1 & 2 & إقامة دورات تدرييبة فعالة للطلاب لربط التطليم النظرى بالواقع العملى & 4 \\
\hline 4 & 2.1 & 2 & توفير المطلم المتخصص المدرب فى كل مجال على حدة & 5 \\
\hline 5 & 2.1 & 2 & انشاء مصاتع وتوفير ها لخر & 6 \\
\hline
\end{tabular}




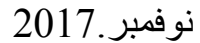

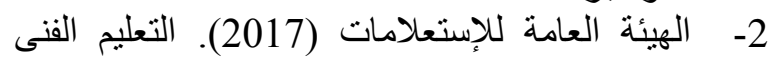

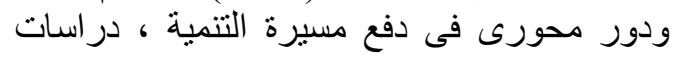
محلية . مورج محر

3- أخبار التعليم - ممبزات التعليم الفنى بالنسبة للطلبة

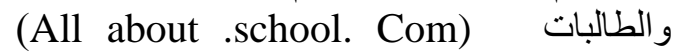
24/12/2017

4- حافظ ؛ أحمد ؛ أبو النصر(2413/2013). اتفاقية مع الإتحاد

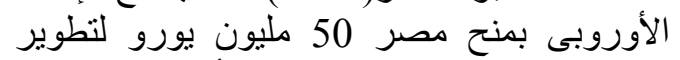

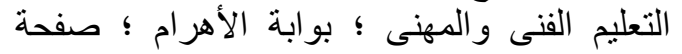
محليات ؛ 16 ديسمبر . 5- حسن ، سـيد دسوقي (2012) ـ فيعير ، في حوار له بجريدة

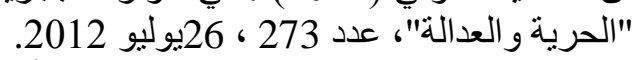

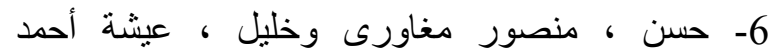

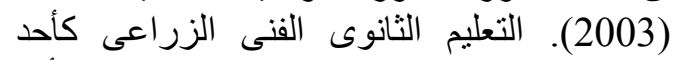

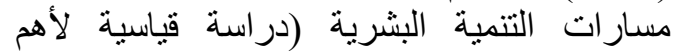

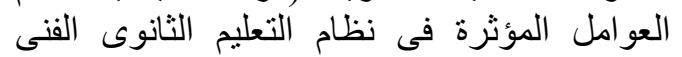

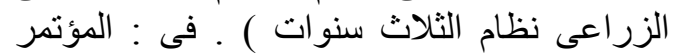

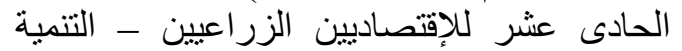
البشرية فى القطاع الريفى، الجمعية المصرية الزية الزئية

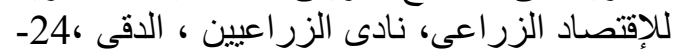
2003. 25 سبتمباد الزراعب ناع (2018

7- حشاد ، زكريا (2018) ـ الإهتمام بالتعليم الفنى أساس

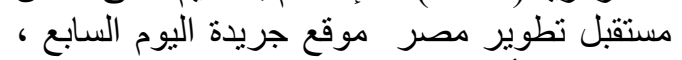

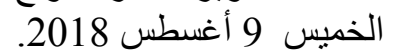

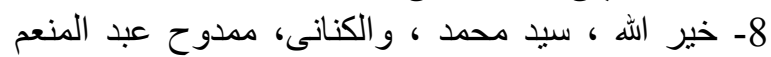

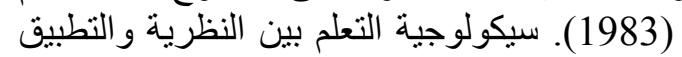

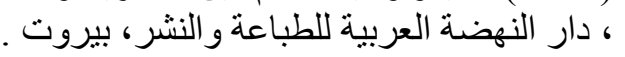
9 - دستور مصر ، الموقع الرسمى للجنة الخمسين لتعديل لنوريل الدستور - dostoure.eg/2013/topic/basic compoments/cultural

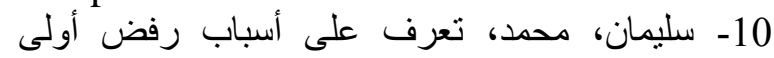
الجمهورية (تعليم زر اعى) الإلتحاق بالثانوية، اليوفي الئى

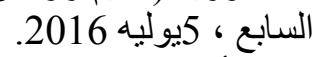

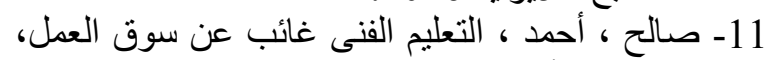

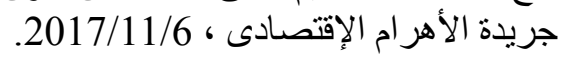

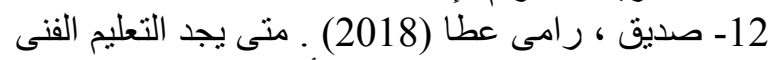

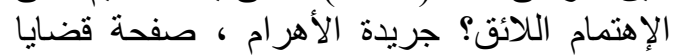

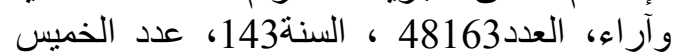

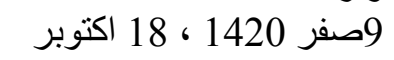

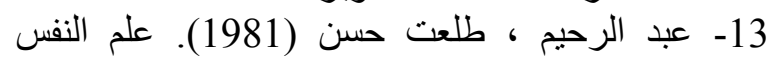
الإجتماعى المعاصر، الطبعة الثانية دار الثقافة الثرة

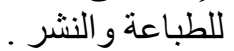

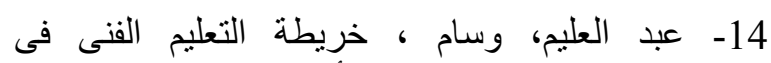

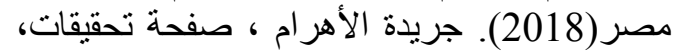
السبت 24 نوفمبر.

15- عبد الفتاح ، عبد الرزاق، التعليم الفنى والتدريب، المؤتمر الثامن ، مصر (2000). التعليم فى مصر ، النّان،
للخريجين فى صورة مشرو عات تدر عليهم دخل وتبسير

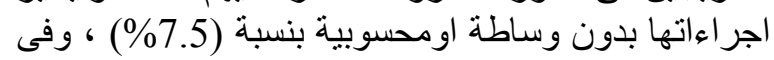

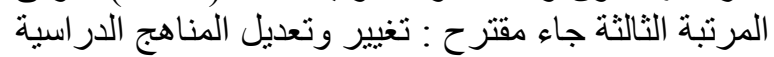

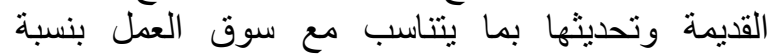
(4.2\%) ،وفى المر اتب: الر ابعة و الر ابعة مكرر و الخامسة

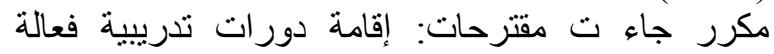
للطلاب لربط التعليم النظرى بالو اقع العملى، وتوفير المعلم

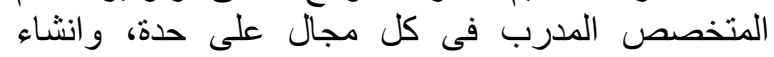
مصانع وتوفيرها لخريجى التعليم الفنى بالمدن الصنى الصناعية الجديدة بنسبة (2.1\%) لكل منها على الترتيب.

\section{توصيات البحث فى ضوء نتائج البحث يمكن التوصية بما يلى:}

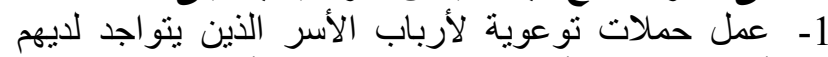

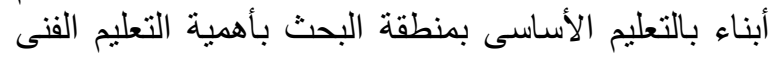

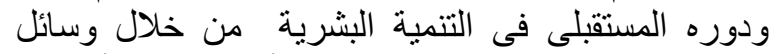

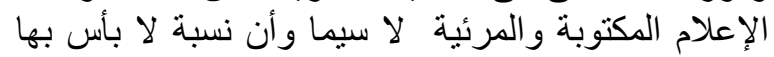

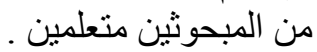

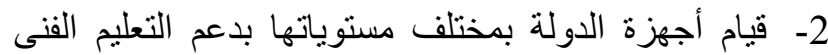
بداية من تغيير النظرة المتدنية نحوه وحتى بناء الثقة فى لئ

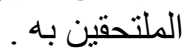
3- تدعيم اتجاهات ارباب الأسر الريفيين لا سيما أصحاب

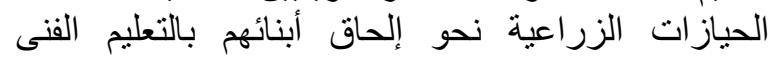

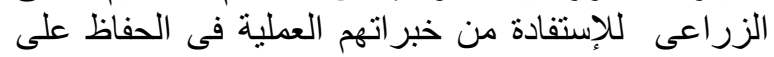

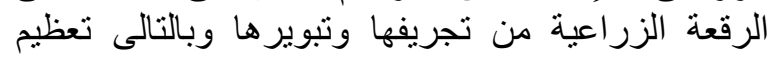

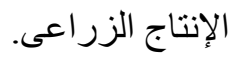

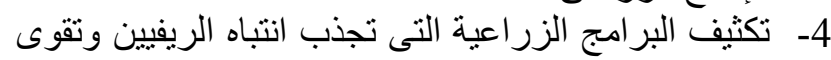

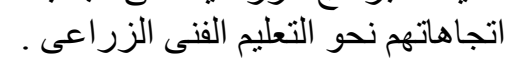

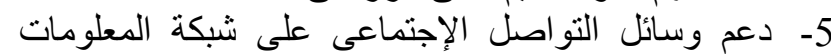

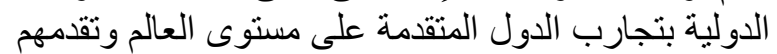

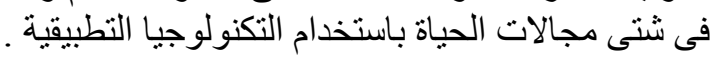

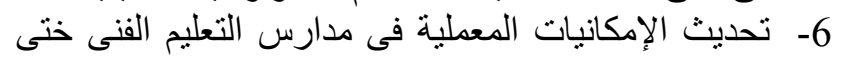

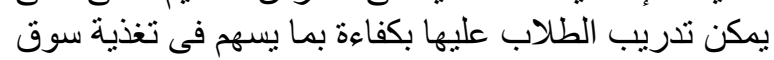

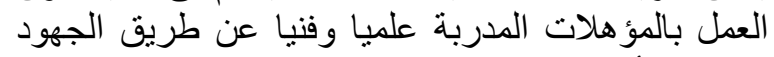

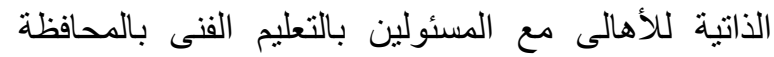
و إدار اتها التعليمية. لأهلى

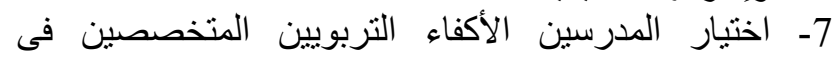

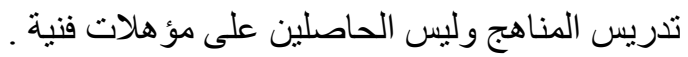
8- زيادة الاهتمام بالتعليم الصناعى وتوفير الإمكانيات وتذاليل الطيل

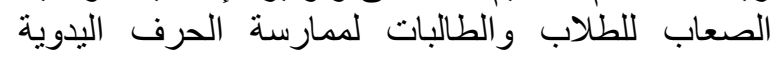

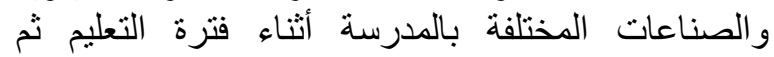

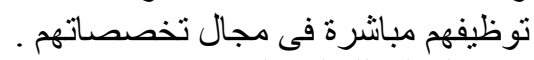

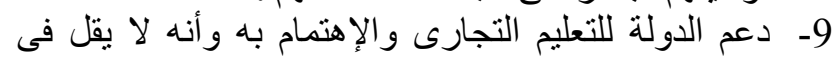

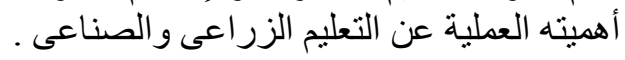

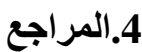

1- الجهاز المركزى للتعبئة العامة والإعة الإحصاء(20162017). النشرة السنوية لإحصاءعات الخداء الخدمات

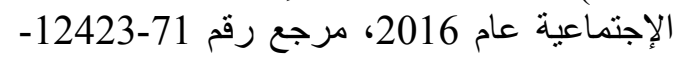


1991

20- مجلة صناع المستقبل (2015). أهمية التعليم الفنى

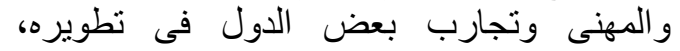

إعلامية شهرية يصدرها مكتب العاريات الإقات العامة

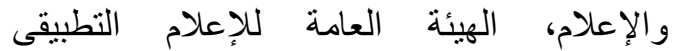

والتدريب، الكويت، العدد الأول، السنة الثالثة

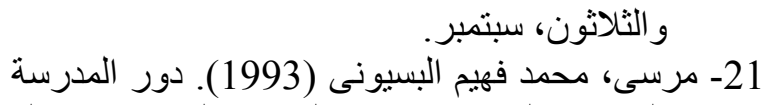

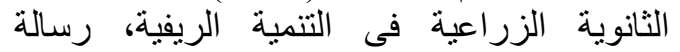

ماجستير ؛ كلية الزر اعة ـ جامعة الأزهر ، الزية القاهرة.

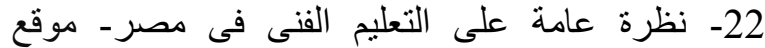

7/11/2010 tawgeh.yoo7.com

23- نشوانى ، عبد المجيد (1983). علم النفس التربوى، الري،

دار الفرقان، إربد، عمان، الأردن .

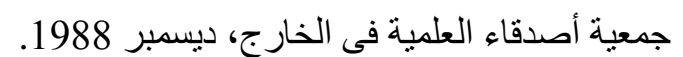

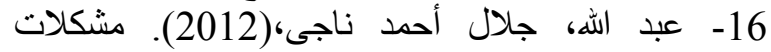

مخرجات التعليم الفنى والتدريب المهنى فئل في بيئة

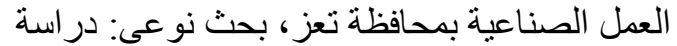

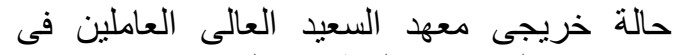

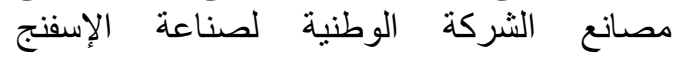
و البلاستيك.

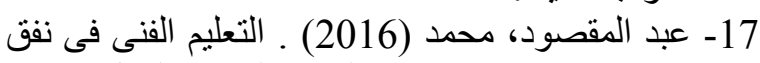

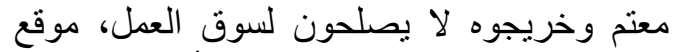

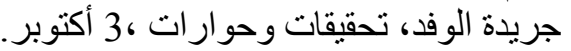

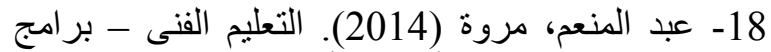
طموحة وواقع أليم، الأهرام المسائى، صنحة صنحة تحقيقات؛ العدد 8551 ، 25 سبتمبر.

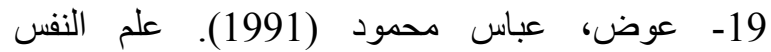
الإجتماعى، دار المعرفة الجامعية، الإسكندرية، 